\title{
Complex interaction of adiponectin-mediated pathways on cancer treatment: a novel therapeutic target
}

\author{
Massimo Monks ${ }^{1}$, Foivos Irakleidis ${ }^{2}$, Peng H. Tan ${ }^{2}$ \\ 'UCL Medical School, Faculty of Medical Science, Royal Free NHS Foundation Hospital, London NW3 2QG, UK. \\ ${ }^{2}$ Breast Unit, Department of Surgery, Royal Free NHS Foundation Trust, London NW3 2QG, UK.
}

Correspondence to: Dr. Peng H. Tan, Breast Unit, Department of Surgery, Royal Free NHS Foundation Trust, Pond Street, London NW3 2QG, UK. E-mail: peng.tan@nhs.net

How to cite this article: Monks M, Irakleidis F, Tan PH. Complex interaction of adiponectin-mediated pathways on cancer treatment: a novel therapeutic target. J Cancer Metastasis Treat 2019;5:24. http://dx.doi.org/10.20517/2394-4722.2018.79

Received: 11 Nov 2018 First Decision: 21 Dec 2018 Revised: 7 Jan 2019 Accepted: 14 Feb 2019 Published: 29 Mar 2019

Science Editor: Umberto Galderisi Copy Editor: Cai-Hong Wang Production Editor: Huan-Liang Wu

\begin{abstract}
Obesity has the far reaching consequence on cancer pathogenesis and immune reactions. In particular, adiponectin (APN) produced by adipocytes played an important role in modulating obesity related malignancies. $V i a$ its interaction with corresponding receptors and their downstream signalling pathways, it regulates cells survival, apoptosis and cancer metastasis. Our review dissects the clinical evidence on how hypoadiponectinaemia associated with the increased risks of several cancers and the long-term prognosis and also addresses the controversies. APN also has its indirect effect on anti-cancer immune response which may influence the disease process. We also analyse the impact of APN on the immune system, the anti-tumour responses and the controversies surrounding this area. Targeting therapeutics on APN and its receptor axis represents a promising and novel anti-cancer treatment. Biological understanding of how APN and its interaction with its receptors may affect the immune reactivity. Careful strategizing the use of APN therapeutics in cancer treatment is important, as the APN receptor signalling on the immune cells can blunt anti-tumour response. Targeting APN or its receptors has an enormous implication for the treatment of cancers.
\end{abstract}

Keywords: Adiponectin, AdipoR1/R2, Cancer, signaling pathway, anti-tumor immunity, therapeutic targets

\section{INTRODUCTION}

Adipose tissue is no longer seen as only a passive energy store, but instead a complex metabolic and endocrine organ. Composed of adipocytes, nerve tissue, connective tissue matrix, stromo-vascular cells that

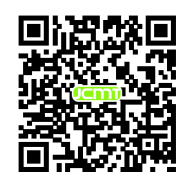



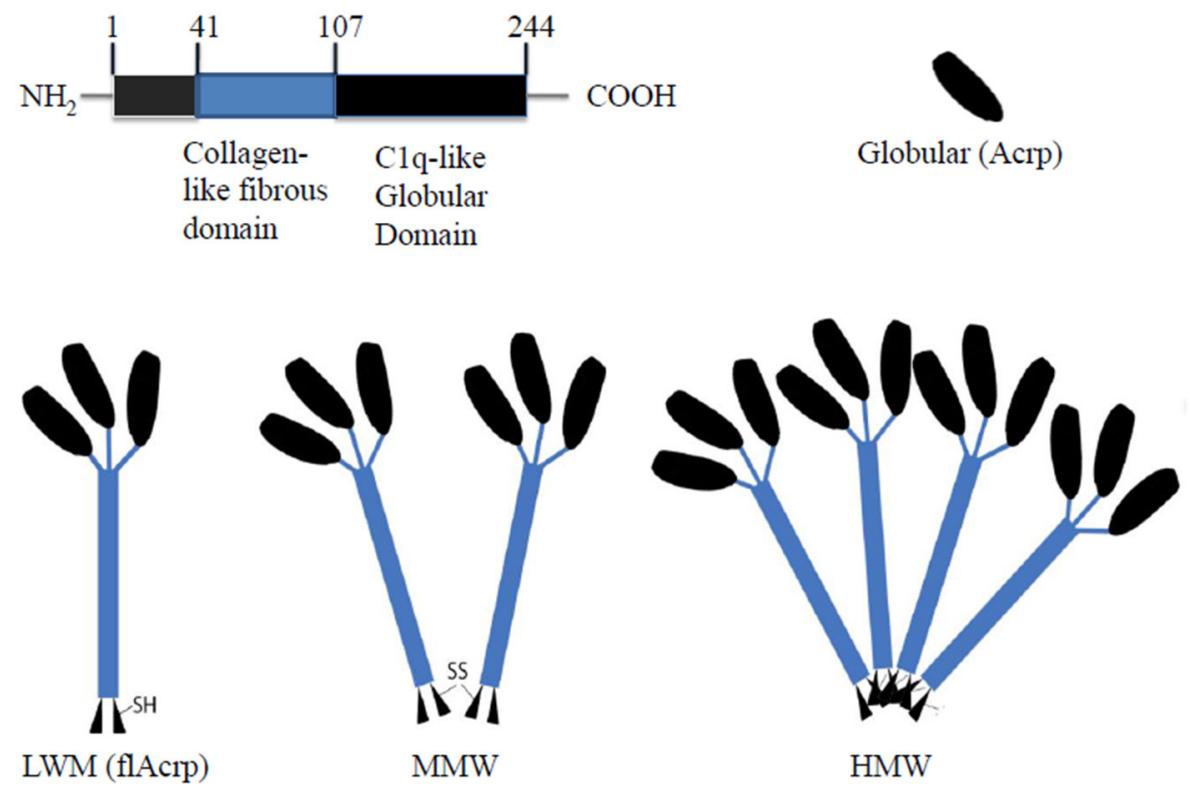

Figure 1. Structure of APN. Low molecular weight. MMW: middle molecular weight; HMW: heavy molecular weight; flAcrp: full length adiponectin; Acrp: globular adiponectin

can orchestrate the immune cells. It expresses, secretes, and responds to a number of key cellular modulators which may have a prominent role in the development and regulation of the disease process in the body ${ }^{[1]}$. Adipocytes secrete cell signalling proteins, termed adipokines, of which adiponectin (APN) has been shown to have anti-inflammatory ${ }^{[2]}$, anti-atherogenic ${ }^{[3]}$, and anti-diabetic properties ${ }^{[4,5]}$.

With obesity being linked to approximately $20 \%$ of all cancers ${ }^{[6]}$, harnessing APN may be of great therapeutic benefit, especially with obesity-related cancer. For this to be successful, it is important to note that adipokines can have both anti-inflammatory and pro-inflammatory properties ${ }^{[4]}$. When the homeostasis is disrupted, these molecules have the ability to cause harm, yet if we are able to counteract the imbalance, adipokines could pose an important anti-carcinogenic target for the future.

\section{BACKGROUND OF APN AND ITS RECEPTORS}

\section{Discovery of APN and its structure}

APN was first described in 1995 by Scherer et al. ${ }^{[7]}$ from a cDNA library containing adipocyte-specific genes. Monomeric APN is a $30-\mathrm{kDa}$ glycoprotein encoded by the ADIPOQ gene on human chromosome 3q27. APNs full-length protein (flAcrp) structure was discovered three years later and structurally resembled complement protein $\mathrm{C} 1 \mathrm{q}$ and proteins from the tumour necrosis factor (TNF) family ${ }^{[8]}$. It consists of a $\mathrm{N}$-terminal region, a hyper-variable sequence, a collagen-like fibrous domain linked to a C-terminal C1qlike globular domain [Figure 1]. Similarities between APN and C1q are seen in folding topology, intron positions, and the formation of trimers. Interactions between the collagen-like domains of three monomeric APNs form the low-molecular-weight (LMW) isoform. The LMW isoform then has the ability to form stable multimeric oligomers. Two LMW isoforms can connect via a disulphide bond to form a middle molecular weight (MMW) hexamer. With the help of post-translational modifications larger 12- or 18-mer high molecular weight (HMW) isoforms are generated ${ }^{[9]}$.

The majority of APN is produced by white adipose tissue, with lower quantities being produced form brown adipose tissue $^{[10]}$. That said, several studies have demonstrated APN being present much lower concentrations in other tissues: cerebrospinal fluid ${ }^{[11]}$, cardiomyocytes $^{[12]}$, skeletal muscle ${ }^{[13]}, \operatorname{liver}^{[14]}$, and bone marrow ${ }^{[15]}$. The different isoforms are found at varying concentrations throughout the body. The monomeric isoforms 
are confined to adipocytes, the oligomeric isoforms are present in the circulation ${ }^{[16]}$, and the globular form (gAcrp) trimerise to form a stable complex in the circulation.

These different isoforms are thought to have varying biological effects with the HMW isoform being the most biologically active and having the highest plasma concentration. The normal plasma concentration levels of APN range from 2-30 g/mL $\mathrm{mL}^{[17]}$. APN levels have been shown to be altered in many disease processes. Coronary heart disease ${ }^{[18]}$, atherosclerosis ${ }^{[18]}$, type 2 diabetes ${ }^{[19]}$, obesity ${ }^{[20]}$, insulin-resistance ${ }^{[20]}$, and many cancers are correlated with lower APN levels. Understanding how different isoforms exert effects upon various tissues may be central to understanding the pleiotropic actions of APN within the body.

\section{APN receptors}

Three receptors are known to bind with APN: AdipoR2 $1^{[19]}$, AdipoR $2^{[19]}$, and T-cadherin ${ }^{[21]}$. AdipoR1 and AdipoR2 have an internal N-terminal region and an external C-terminal region with a central seven transmembrane domain. The topology of these receptors are extremely similar, sharing $67 \%$ of their protein sequences ${ }^{[22]}$. However, compared to G-protein coupled receptors, their topology is completely opposite. AdipoR1 shows high-affinity binding to globular APN, and also binding to full-length APN and is highly expressed in skeletal muscle. While AdipoR2 shows intermediate-affinity binding to both forms and is predominantly expressed in the liver. More recently, T-cadherin was identified as an additional APN receptor $^{[21]}$. It is a glycosylphospatidylinositol-anchored protein that is highly expressed in endothelial and smooth muscle cells, and has shown specific binding to MMW and HMW isoforms ${ }^{[23]}$.

\section{APN AND CANCER}

A number of cancers have been correlated with hypoadiponectinemia and altered levels of AdipoR1/R2 and T-cadherin. Therefore, APN may be a novel modifiable risk factor with uses as a prognostic or diagnostic biomarker.

\section{Colorectal cancer}

It has been long acknowledged that obesity, hyperinsulinaemia, and insulin-resistance are associated with colorectal cancer (CRC) pathogenesis. More recently it has been shown that APN levels are negatively correlated with a risk of developing CRC [Table 1]. This has been confirmed by three meta-analyses ${ }^{[2-26]}$ and multiple studies summarised in Table 1. Not only did CRC patients have lower levels of APN, but one study showed that men with high APN had a $60 \%$ reduced risk of $\mathrm{CRC}^{[27]}$. A following study showed a similar reduced risk in CRC among men, however no link was seen in females ${ }^{[28]}$. This highlights the point that the expression and response to APN can differ between sexes. APN also seems to have a role at the later stages of CRC and an influence on its clinicopathological characteristics. Two studies showed an inverse correlation between tumour stage/grade and $\mathrm{APN}^{[29,30]}$. Furthermore, low pre-surgical APN levels were found in a higher proportion of relapsing patients, suggesting that APN may have potential to act an adjunctive tool to predict relapse. Mice knock-out models have suggested that interactions with AdipoR1, rather than AdipoR2, have a more protective role as only AdipoR1-KO mice demonstrated increased proliferative activity ${ }^{[31]}$.

To aid development of any therapy it is important to understand changes that occur to APN within CRC tumour cells. FlAcrp can be post-translationally modified to Acrp within the tumour environment, such that the ratio between flAcrp:Acrp is higher than in the surrounding normal tissue ${ }^{[32]}$. Local conversion to Acrp could help create a more beneficial tumour environment by functioning in an autocrine manner ${ }^{[33]}$. Thus, not only do CRC patients often have lower circulating levels of APN, but also a different proportion of APN subtypes that benefit tumour progression.

\section{Gastric cancer}

APN levels have been shown to have an inverse correlation to gastric cancer (GC) [Table 1]. One study found that GC cells lacking AdipoR1 had higher peritoneal dissemination and lymphatic metastases than AdipoR1 


\section{Table 1. Epidemiological studies showing the relationship of serum APN and cancer}

\begin{tabular}{|c|c|c|}
\hline Study types & Study outcome & Ref. \\
\hline \multicolumn{3}{|c|}{ Colorectal cancer - CRC } \\
\hline \multirow[t]{5}{*}{ RCC } & $\begin{array}{l}P<0.001 ; P=0.037 \\
\text { 1. APN is significantly lower in CRC; } \\
\text { 2. APN inversely correlates to tumor stage; } \\
\text { 3. Lower APN is associated with CRC recurrence }\end{array}$ & {$[29]$} \\
\hline & $\begin{array}{l}P<0.05 \\
\text { 1. Lower APN; } \\
\text { 2. No correlation visceral fat \& APN in CRC or adenoma }\end{array}$ & {$[67]$} \\
\hline & $P<0.001$ - Lower APN in CRC & {$[68]$} \\
\hline & $\begin{array}{l}\text { 1. } O R=0.0802(0.321-1.003) \text { for } C R C \text { risk } \\
\text { 2. } O R=0.442(0.189-0.946) \text { for adenoma risk }-A P N \text { is good marker for adenoma }\end{array}$ & {$[69]$} \\
\hline & $\begin{array}{l}\text { OR }=0.72(0.53-0.99) \text { for } C R C \text { risk, } P=0.005 \text { - Lower APN correlates to CRC risk and APN inversely } \\
\text { correlates to tumor grade }\end{array}$ & {$[30]$} \\
\hline \multirow[t]{5}{*}{ PCC } & $\begin{array}{l}\text { 1. } R R=0.55(0.35-0.86), P=0.02 \text { for men highest } v s \text {. lowest quartile } \\
\text { 2. } R R=0.96(0.67-1.39), P=0.74 \text { for women } \\
\text { APN significant associated with reduced risk in men but not women }\end{array}$ & [28] \\
\hline & $\mathrm{RR}=(0.23-0.78) ; P($ trend $)=0.01-$ Men with low APN had a higher risk of CRC & {$[27]$} \\
\hline & $\begin{array}{l}\text { 1. } R R=0.71(0.53-0.95), P=0.03 \text { for total APN when comparing highest } v s \text {. lowest quintile } \\
\text { 2. RR }=0.45,(0.34-0.61), P<0.0001 \text { for non-HMW APN } \\
\text { Total \& non-HMW APN inversely correlates to CRC risk }\end{array}$ & {$[70]$} \\
\hline & $\begin{array}{l}P>0.05 ; \text { OR }=0.8(0.5-1.4) \text { for highest } v s . \text { lowest APN quartile } \\
\text { No significance correction between APN \& CRC risk }\end{array}$ & {$[71]$} \\
\hline & $P>0.05$ - No significance association & {$[72]$} \\
\hline \multicolumn{3}{|c|}{ Gastric cancer - GC } \\
\hline \multirow[t]{2}{*}{ RCC } & $P=0.0004-$ APN levels were significantly lower in Stage I cases than controls & {$[73]$} \\
\hline & $\begin{array}{l}P<0.005 \text { - Negative correlation with pathologic findings such as tumor size, depth of invasion, tumor } \\
\text { stage (only in undifferentiated GC) }\end{array}$ & {$[74]$} \\
\hline RCC & $\begin{array}{l}P>0.005 \text { - No significant difference in tumor stage, localization, nodal status, lymphatic and vascular } \\
\text { invasion }\end{array}$ & {$[75]$} \\
\hline \multicolumn{3}{|c|}{ Oesophageal cancer - OC } \\
\hline \multirow[t]{4}{*}{ RCC } & $\begin{array}{l}P<0.05 ; P<0.05 \text { - Significantly lower APN levels in ESCC \& EA patients than controls } \\
\text { EA patients had lowered APN than ESCC }\end{array}$ & {$[76]$} \\
\hline & $\begin{array}{l}\mathrm{HR}=0.34(0.14-0.82)-\text { Nonlinear inverse association with risk of EA; the strongest associations were } \\
\text { observed in } 2 \text { nd tertile }\end{array}$ & {$[77]$} \\
\hline & $P=0.01-$ Serum APN was significantly lower in cases than controls & {$[78]$} \\
\hline & $P=0.802-$ APN levels were similar in various esophageal pathologies & {$[79]$} \\
\hline \multicolumn{3}{|c|}{ Breast cancer - BC } \\
\hline \multirow[t]{7}{*}{ PCC } & $\begin{array}{l}\text { 1. Adjusted } \mathrm{OR}=0.2(0.0-0.6) ; P<0.05 ; 80 \% \text { reduced risk in higher APN compared with stage I-III }{ }^{[41]} \\
\text { 2. Adjusted } \mathrm{OR}=0.04(0.071-0.99)-\text { Lower } \mathrm{APN} \text { in early breast cancer vs. healthy controls }{ }^{[80]} \\
\text { 3. } P=0.04-65 \% \text { reduced risk in higher APN compared with stage I-III }{ }^{[40]}\end{array}$ & {$[40,41,80]$} \\
\hline & $\begin{array}{l}\text { 1. } P<0.005 \text { (for tumor size); } P<0.05 \text { (for grade); }>2 \mathrm{~cm} \text { tumor } \& \text { Grade } 2 \& 3 \mathrm{BC} \text { cases were higher in } \\
\text { lower tertile of serum } \mathrm{APN}^{[42]} \\
\text { 2. } P=0.036 \text { - Negative correlation with tumor size }{ }^{[43]}\end{array}$ & {$[42,43]$} \\
\hline & $P($ trend $)=0.0270-$ Inverse trend in ER/PR - ve BC (for not +ve) & [44] \\
\hline & Adjusted HR $=0.39(0.15-0.95)-$ Higher APN was associated longer BC (stage I-IIIA) survival & {$[81]$} \\
\hline & $\begin{array}{l}\text { Adjusted } \mathrm{HR}=0.88(0.81-0.96) ; P=0.03 ; \text { Lower } \mathrm{APN} \text { was associated with a history of prior } \mathrm{pT1mic} / \mathrm{pT} 1 \mathrm{a} \\
\& \text { higher risk of second } \mathrm{BC} \text { in premenopausal and } 12 \% \text { reduction in risk of } \mathrm{BC} \text { per unit increase of APN } \\
\text { 1. } P=0.017^{[83]} \\
\text { 2. OR }=0.805(0.704-0.921) ; P=0.00^{[84]} \\
\text { Lower APN was associated with nodal disease }{ }^{[83,84]}\end{array}$ & $\begin{array}{l}{[82]} \\
{[83,84]}\end{array}$ \\
\hline & $\begin{array}{l}\text { Post-menopausal OR }=0.73(0.55-0.98) \text { but pre-menopausal } O R=1.30(0.80-2.10) \text { (all women OR }=0.89 \\
(0.71-1.11) \\
\text { Negative correlation in post-menopausal women }\end{array}$ & [85] \\
\hline & $P=0.43$ for linear trend - No association with risk & [45] \\
\hline \multicolumn{3}{|c|}{ Endometrial cancer - EC } \\
\hline \multirow[t]{2}{*}{ PCC } & $\begin{array}{l}\text { OR }=0.56(0.36-0.86) \text { highest vs. lowest APN quartile } \\
\text { Negative correlation independent of other obesity-related risk factors }\end{array}$ & {$[86]$} \\
\hline & $\begin{array}{l}\mathrm{OR}=0.42(0.19-0.94) \text { comparing highest } v s \text {. lowest tertile } \\
\text { Inverse association with risk of EC } \\
\text { Stronger association in pre-menopausal than post-menopausal }\end{array}$ & {$[48]$} \\
\hline $\mathrm{RCC}$ & $\begin{array}{l}\text { OR }=0.52(0.32-0.83) ; P<0.001-\text { Significant negative correlation between APN level and EC risk } \\
P<0.001 ; P<0.05 \text { - Significantly lower APN in EC patients than normal or polyps epithelium patients } \\
P<0.0001-\text { Significantly reduced APN in cases than controls; } \\
\text { Leptin:APN ratio correlated to post-menopasual EC risk }\end{array}$ & $\begin{array}{l}{[87]} \\
{[88]} \\
{[89]}\end{array}$ \\
\hline
\end{tabular}


PCC

All Women: $O R=0.86$ (0.53-1.39) and Post-menopausal: $O R=0.66(0.29-1.50)$

Non-significant result (pre-diagnostic APN is not predictive of EC risk)

Pancreatic cancer - PC

PCC OR $=0.44(0.23-0.82)-$ In never smoker, higher APN levels correlated to reduced risk of PC;

$\mathrm{OR}=1.59(0.67-3.76)-$ No significance in smoker

$\mathrm{OR}=0.55(0.31,0.98) ; P=0.03$ for highest $v s$. lowest quintile - Higher APN were negatively correlated with $\mathrm{PC}$ risk

Nonlinear association $(P<0.01)$ - Low pre-diagnostic levels of APN were associated with an elevated risk of $\mathrm{PC}$

RCC

$P=0.0035$ - Median APN levels significantly higher in PC group than controls/chronic pancreatitis group

$P<0.001$ - Greater APN:Leptin ration in PC patients

$\mathrm{OR}=2.81$ (1.04-7.59) - Higher APN correlated with higher odds of PC and No association with PC stage

Renal cell carcinoma - RCC

RCC

$\mathrm{OR}=0.76(0.57-1.00) P=0.05-$ Serum APN negatively correlated with RCC risk

$P<0.01$ (tumor size); $P=0.029$ (non-metastatic $v s$. metastatic); $P=0.044$ for total APN \& $P=0.041$ for

HMW (non-metastatic vs. metastatic) - Strong inverse correlation was found between plasma APN levels and tumor size ${ }^{[57]}$; Lower APN in metastatic cases $^{[57,58]}$

OR $=2.3(1.1-4.6)$ - Higher APN was associated with RCC risk among African American males

Hepatic cancer - HC

PCC OR $=0.5(0.22-1.15)$ for highest $v s$. lowest tertile for LMW APN - Higher \% of LMW APN may be have a protective effect on $\mathrm{HC}$

RCC $\quad P=0.670 ; P=0.752-$ No significance difference between cases and controls

Prostate cancer - PrC

PCC OR $=0.27(0.07-0.87)$ for highest vs. lowest quintile for lethal $\operatorname{PrC}-$ Men with higher APN had reduced risk of $\mathrm{HG}$ or lethal Prc but overall no significant correlation between serum APN \& PrC risk

NCC OR $=0.86(0.66-1.11), P=0.24$ for all men;

$\mathrm{OR}=0.62(0.42-0.90), P=0.01$ for obese $\&$ overweight men

APN levels negatively associated with $\operatorname{PrC}$ risk in obese $\&$ overweight men but not significant in all men

RCC OR $=0.29(0.10-0.89)$ for highest $v s$. lowest quartile - Reduced risk with higher APN independent of various confounders

$P<0.05$ - Significantly reduced APN in PrC patients

$P<0.001$ - APN levels in HG PrC were also significantly lower than LG or IG groups

PCC

$\mathrm{OR}=0.87(0.46-1.65)$ for highest $v s$. lowest tertile - No significance but the sensitivity of assays used was

Lung cancer - LC

RCC problematic

$P<0.0001$ - Leptin: APN ratio was significantly lower in the patients group compared to controls

$\mathrm{OR}=1.13$ (0.80-4.97); OR = 0.25 (0.10-0.78) - Even though APN levels were not significantly different in cases than controls but they are significantly lower in advanced than limited disease stage

$P>0.05^{[100]} ; \mathrm{OR}=2.00(0.80-4.97), P=0.14^{[101]}-$ No significance
$[100,101]$

A summary on the clinical data showing the association of serum APN with various cancers is shown. Many studies show that low levels of APN is associated with cancer risk and its progression of disease. CRC: Colorectal cancer; PCC: prospective case-control; RCC: Retrospective case-control; NCC: nested case control; OR: odd ratio; RR: relative risk; BC: breast cancer; EC: endometrial cancer; GC: gastric cancer; OC: oesophageal cancer; ESCC: esophageal squamous cell cancer; EA: esophageal adenocarcinoma; PC: pancreatic cancer; HC: liver cancer; RCC: renal cell cancer; PrC: prostate cancer; HG: high grade; LG: low grade; IG: intermediate grade

positive cells ${ }^{[34]}$. Despite, the AdipoR1 positive group having longer survival rates, multivariate analysis indicated this was not an independent prognostic factor on GC survival. That said, it is thought AdipoR1 is the mediator of tumour growth suppression in GC and therefore could be a therapeutic target in tackling GC. One study demonstrated that rs266729, an ADIPOQ variant, may be an independent prognostic factor for non-drinking GC patients receiving surgical treatment ${ }^{[35]}$. Similarly, APN levels have been shown to have a direct effect in GC postoperative outcomes. It was shown that the ratio of postoperative to preoperative levels of APN was the most useful predictor for postoperative infection ${ }^{[36]}$. It is thought that reduced APN levels suggest a submaximal inflammatory response, thus predisposing to infection ${ }^{[32]}$. Increasing APN in the weeks before surgery could be an additional method to improve surgical outcomes.

\section{Oesophageal cancer}

APN plays a significant role in the maintenance of the normal oesophageal mucosa ${ }^{[32]}$. Lower levels of APN have been correlated with an increased risk of oesophageal cancer (OC) [Table 1]. Low tumour expression of AdipoR1 was suggested to be an independent predictor of improved overall OC survival ${ }^{[37]}$. While, AdipoR2 
expression was inversely correlated with tumour size. It was shown that low levels of LMW and high levels of HMW APN compared to the total APN ratio increased the risk of Barrett's oesophagus, which contributes to OC propagation ${ }^{[38]}$. Looking at the dynamic changes between LMW and HMW APN levels during OC transformation could present an interesting predictive biomarker.

\section{Breast cancer}

A recent meta-analysis confirmed a link between hypoadiponectinaemia and an increased breast cancer (BC) risk $^{[39]}$. This increased risk was only found in post-menopausal women and not pre-menopausal women. Risk reduction in early BC patients with high APN levels has been reported to be from $65 \%-80 \%{ }^{[40,41]}$. A negative correlation has been demonstrated between APN levels and tumour size and grade ${ }^{[42,43]}$. Interestingly, the correlation between APN and $\mathrm{BC}$ seems to be more prominent in oestrogen-negative and progesteronenegative $\mathrm{BC}^{[44]}$. Therefore, it seems there may be a set group of $\mathrm{BC}$ patients that are most susceptible to the effects of APN and would benefit most from a potential treatment. That said, certain studies have shown no correlation between APN and BC risk ${ }^{[45]}$.

\section{Endometrial cancer}

A significant negative correlation has been found between levels of APN and endometrial cancer (EC) ${ }^{[46]}$ [Table 1]. A meta-analysis found that high levels of APN reduced the risk of EC by $53 \%{ }^{[47]}$. Whether APN levels effect pre- or post-menopausal women is unclear as studies have produced varying results ${ }^{[47-49]}$. One proposed protective mechanism of action is that APN can reduce the number of EC cells by inhibiting proliferation and stimulating apoptosis ${ }^{[49,50]}$. One study looked into the serum levels of the APNs isoforms and found that low levels of MMW isoform were the only independent risk factor for $\mathrm{EC}^{[51]}$. It is unclear why this isoform in particular was most closely associated with EC, but highlights the pleiotropic effects APN exerts through its multiple isoforms.

\section{Pancreatic cancer}

The association between APN levels and pancreatic cancer (PC) is unclear from current studies [Table 1]. Some studies demonstrated a negative correlation between serum APN and $\mathrm{PC}^{[52]}$, while others showed high APN levels increasing the risk of $\mathrm{PC}^{[53]}$. Of note, high APN levels were associated with a reduced PC risk in people that never smoked, but no significance found in smoker ${ }^{[54]}$. PC has significant mortality associated with its diagnosis with a 5 -year survival of only $9 \%{ }^{[55]}$, therefore early detection using biomarkers could significantly alter treatment and prognosis. However, further prospective studies are needed to confirm APN as a PC marker.

\section{Renal cancer}

A negative correlation has been shown between serum APN and renal cancer (RCC), tumour stage, and metastasis $^{[56-58]}$. That said, one study showed how APN may exert different effects depending on ethnicity as a positive correlation was found between APN and RCC in African Americans but not Caucasians ${ }^{[59]}$.

\section{Prostate cancer}

A negative correlation between APN levels and prostate cancer $(\mathrm{PrC})$ tumour grade and stage has been demonstrated in several studies [Table 1]. One study showed that the reduced risk was only found in obese and overweight men, but not all men ${ }^{[00]}$. Furthermore, four ADIPOQ single nucleotide polymorphisms (SNP) (rs266729, rs182052, rs822391 and rs2082940) were shown to be significantly associated with PrC risk in Caucasians ${ }^{[61]}$. Once again highlighting the differing effects of APN in different ethnicities.

\section{Hepatic cancer}

The relationship between hepatic cancer (HC) and APN levels is unclear [Table 1]. Certain studies showed that higher APN levels predicted a poorer survival with $\mathrm{HC}^{[62]}$. APN expression pairs with tumour size but not several other parameters, therefore the rise in APN with tumour tissue may occur throughout the 
process of carcinogenesis in an attempt to counteract the change and restore ${ }^{[32]}$. Others studies suggested poor HC prognosis was associated with lower AdipoR1/R2 expression ${ }^{[63]}$. AdipoR1 expression was correlated with the absence of vascular invasion and AdipoR2 was associated with a low stage and a lower histological grade. Although the role of APN in HC is unclear, APN may have a role pre-malignant hepatic conditions such as non-alcoholic steatohepatitis $(\mathrm{NASH})^{[32]}$. APN can suppress the hepatic damage caused by TNF- $\alpha$ in early NASH, thus highlighting an area where targeted APN treatment could help halt progression to cirrhosis and cancer.

\section{Lung cancer}

The majority of studies have not found a significant correlation between APN levels and lung cancer (LC) [Table 1]. Yet, one study demonstrated that there were lower levels of APN were present in patients with advanced disease compared to limited stage disease ${ }^{[64]}$. AdipoR1 and AdipoR2 were only expressed in the cancerous tissue, with non-found in normal control tissue. Further studies are needed to determine a link between APN and LC.

\section{Genetic polymorphisms}

Multiple genetic polymorphisms have been associated with altered risk of malignancy in ADIPOQ, ADIPOR1, and ADIPOR $2{ }^{[65]}$. These SNPs have been associated with a wide number of cancers and may enable screening and identification of high risk patients. This can allow for primary preventive measures, such as losing weight, diet, and exercise, as well as chemoprevention ${ }^{[6]}$. Going forward we need to be take into consideration the interaction between various SNPs, ensure that a large and diverse group of the population are screened for more SNPs, and determine how SNPs can be applied to clinical decision making.

\section{DIRECT EFFECT OF APN PATHWAY ON CANCER BIOLOGY}

Insulin resistance and hypoadiponectinemia have been associated with multiple cancers. The binding of APN to AdipoR1/R2 triggers a number of downstream signalling cascades which have effects on cancer biology and anti-cancer immunity. Understanding these pathways can help give light to the multitude of APNs metabolic and immunological effects. These pathways are summarised in Figure 2.

Central to much of APNs actions is the AMP-activated protein kinase (AMPK) pathway ${ }^{[102,103]}$. AMPK can act as a tumour suppressor by modulating inflammation, inducing cell-cycle arrest, and opposing metabolic changes during carcinogenesis ${ }^{[104]}$. AMPK activation has been shown to have a beneficial effect on insulin sensitivity by increasing glucose uptake and fatty acid oxidation in muscles, and inhibiting gluconeogenesis in the liver. Interestingly, disruption of AdipoR1 reduced the AMPK activation, increased glucose production and impaired insulin resistance. While, AdipoR2 disruption enhanced insulin resistance and decreased PPAR $\alpha$ signalling ${ }^{[20]}$. Downstream inhibition of the mTOR pathway contributes to AMPKs tumour suppressive qualities ${ }^{[105,106]}$. This is due to mTORs central role as a regulator of cell growth, autophagy, and cell survival ${ }^{[107]}$. AMPK activation has also been shown to be cytotoxic to cancer cell lines and cause apoptosis via p21 and p53 signalling ${ }^{[108]}$. AMPK has the ability to monitor and respond to cellular energy requirements. In times of hypoxia, nutrient starvation, and redox imbalance, liver kinase B1 (LKB1) - its upstream kinase - activates AMPK. The importance of LKB1 can be seen in patients with PeutzJegher syndrome who are heterozygous for a $L K B 1$ gene mutation. Development of a second mutation in life then greatly increases the risk of multiple cancers. It is hypothesised that the loss of AMPK activation may contribute to this development of malignancy ${ }^{[109]}$. LC and HC patients have shown evidence of LKB1 mutations and low LKB1 expression respectively ${ }^{[104]}$. Therefore, APN mediated AMPK activation could help prognosis and disease progression in these specific cancers.

The PI3K/AKt pathway promotes cellular survival, growth, and proliferation ${ }^{[110]}$. This signalling pathway is specifically known to be involved in gastrointestinal cancers (GI) whereby upstream mutations lead to 


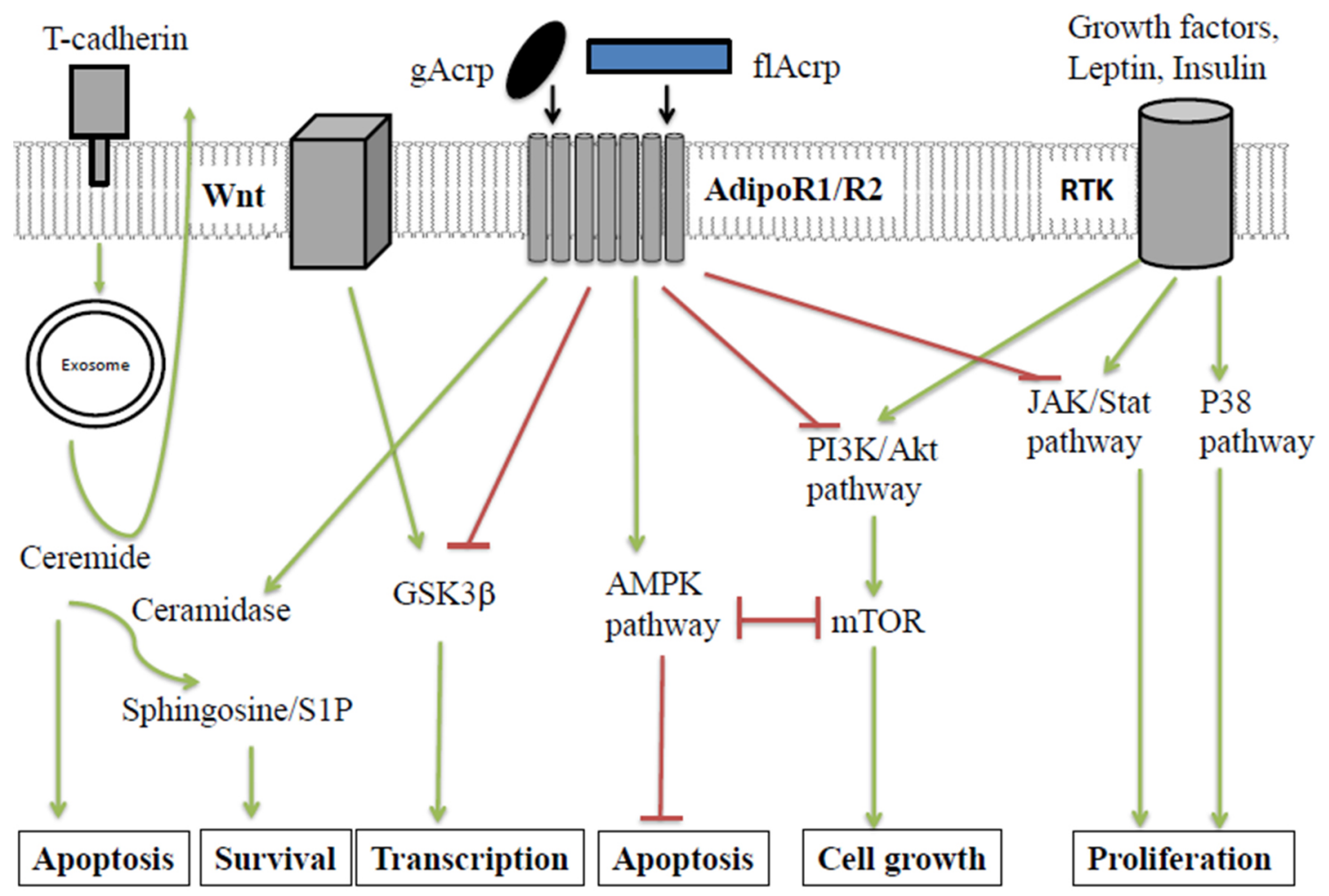

Figure 2. Direct effects of APN on epithelial ells and summary of APNs anti-cancer signalling pathways. In normal epithelial cells, APN is bound by T-cadherin and presented directly or indirectly to AdipoR1/R2 to inhibit signaling pathways activated in neoplasia. APNactivates AMPK, and inhibits PI3K/AKT, mTOR, MAPK and JAK/Stat pathways, or directly affects GSK3 $\beta$ to suppress cancer promoting pathways. Cancer cells down-regulate T-cadherin while AdipoR1/R2 expression persists and cancer-promoting pathways prevail. One model is that ceramidase activity associated with AdipoR1/R2 weighs the balance in favor of cancer cell survival. T-cadherin expressed in the tumor vasculature promotes cancer as a pro-angiogenic factor in cooperation with APN (not shown). Green arrows represent activating pathways. Red lines represent inhibitory pathways. gAcrp: globular adiponectin; flAcrp: full length adiponectin; RTK: receptor tyrosine kinase; JAK: Janus kinases; Stat: signal transducer and activator of transcription proteins; PI3K: PI3-kinases; Akt: protein kinase B; mTOR: mammalian target of rapamycin; AMPK: 5' APM activated protein kinase; GSK3 $\beta$ : glycogen synthase kinase-3 beta

its activation ${ }^{[32]}$. Several factors related to obesity have been shown to induce this pathway and potentially result in carcinogenesis, thus making it a good target for obesity related GI cancer. APN can directly ${ }^{[111]}$ and indirectly ${ }^{[112]}$ inhibit the PI3K/AKt signalling pathway.

APN also interacts with several other pathways that are involved in carcinogenesis and the maintenance of tumour survival including: the Wnt/GSK3B/B-catenin-signalling pathway ${ }^{[13]}$, signal transducer and activator of transcription-3 (STAT-3), and mitogen activated protein kinase (MAPK). APN inhibits STAT3 which has a role in cancer cell proliferation, invasion, and survival ${ }^{[114]}$. STAT-3 promotes pro-oncogenic inflammatory pathways, including NF- $\mathrm{B}$ and IL-6-Janus tyrosine kinase, and inhibits the STAT-1 and NF- $\kappa B$ mediated T helper 1 anti-tumour immune response ${ }^{[114]}$. Both gAcrp and flAcrp have the ability to suppress STAT- 3 and the associated JNK pathways in $\mathrm{HC}$ and $\operatorname{PrC}^{[115]}$. APN also interacts with the MAPK which signals through cJNK, MAPKp38, and extracellular signal-regulated kinases (ERK) $1 / 2^{[40,116,117]}$.

Multiple studies have found that AdipoR1/R2 are over-expressed in cancers. In the setting of hypoadiponectinemia it makes sense to have a compensatory upregulation of the receptors. However, this seems counter-intuitive as the cancer cells are over-expressing receptors that act to hinder their growth and proliferation. It is suggested that in a metabolically deprived tumour environment the cells metabolic needs take priority ${ }^{[17]}$. That said, it has been shown that APN can also have proliferative effects on cancer cells ${ }^{[118]}$. Further studies looking into how the expression of APNs receptors changes throughout tumorigenesis are important as the biological effects of APN depend on the tissue-specific expression of these receptor subtypes ${ }^{[32]}$. 
One of the mechanisms by which APN prevents cancer growth is by promoting apoptosis via cytotoxic autophagy. A recent study using BC cells demonstrated that APN induces an accumulation and fusion of autophagosomes and lysosomes which leads to apoptosis. Central to this pathway is the AMPK mediated activation of the ULK1 (Unc-51 like autophagy activating kinase 1) axis which is regulated by upstream STK11/LKB1 (serine/threonine kinase 11/Liver kinase B1) ${ }^{[119]}$. Autophagy can be cytoprotective, cytotoxic, cytostatic, or non-protective. Due to the cytoprotective role of autophagy many studies have looked to see whether inhibition of autophagy can be used in combination with chemotherapy to increase sensitivity to therapy ${ }^{[120]}$. In contrast, this study has shown that by stimulating cytotoxic-autophagy it can enhance efficacy of chemotherapy. The dual role of autophagy in tumour suppression and promotion makes utilising this pathway therapeutically challenging and more studies are needed to determine how APN induced autophagy can be used in combination with other treatments.

The intracellular accumulation of ceramides have been associated with pathogenesis such as insulin resistance and endothelial dysfunction ${ }^{[121,122]}$. Activation of ceramidase enhances ceramide catabolism to the anti-apoptotic sphingosine-1-phosphate ${ }^{[123]}$. A recent study showed that APN signalling through T-cadherin, but not AdipoR1/R2, reduced cellular ceramide by enhancing exosome biogenesis and secretion ${ }^{[124]}$. This is a novel mechanism by which APN can lower intracellular ceramide and prevent cellular damage. Unlike AdipoR1/R2, T-cadherin is usually downregulated in cancer cells and re-expression of the receptor has been associated with a better prognosis ${ }^{[125]}$. Despite APNs anti-oncogenic pathways, dominance of the ceramidase pathway may enable over expression of AdipoR1/R2 to be pro- rather than anti-oncogenic. When assessing the overall effect of APN, it is important to consider the time at which AdipoR1/R2 are overexpressed in cancer, the concentration of serum APN, and which isoform is circulating.

\section{INDIRECT EFFECT OF APN PATHWAY ON ANTI-CANCER IMMUNITY}

Chronic inflammation in adipose tissue, mediated by adipokine signalling, and immune system dysfunction hold important roles in cancer initiation ${ }^{[126]}$. APN has been shown to have anti-inflammatory properties through interaction with the innate and adaptive immune system [Table 2]. The majority of this is mediated by antigen-presenting cells (APC) of the innate immune system that produce anti-inflammatory cytokines and inhibit pro-inflammatory cytokines. That said, APN has also been shown to have pro-inflammatory effects [Table 2], suggesting that there may be situations where APNs effects shift from anti- to proinflammatory.

One of the central anti-inflammatory cytokines APN induces is IL-10 [Table 2]. The mechanism of IL-10 transcription from APN may be mediated through several pathways. One known pathway is that gAcrp exposure leads to AMPK and ERK1/2 mediated CREB transcription of IL-10 ${ }^{[129]}$. Multiple studies have demonstrated that gAcrp is the best inducer of IL-10. However, one study showed that activation of AdipoR1 by either gAcrp or flAcrp can upregulate IL-10 through the AMPK and MAPKp38 pathway [Figure 3]. IL-10 has a multitude of anti-inflammatory effects ${ }^{[164]}$, one of these may be exerted through activation of the STAT3/ suppressor of cytokine signalling (SOC3) pathway. Activation of the IL-10 receptor activates this pathway which leads to downstream inhibition of NF- $\mathrm{kB}$ [Figure 3].

Although APN levels are generally negatively correlated with cancer risk, high expression of the APN receptors has equally been correlated with tumour progression. Activation of upregulated AdipoR1 and AdipoR2 on dendritic cells (DC) results in the arrest of DCs in an immature state and development of tolerance to tumour antigens ${ }^{[117]}$. Each APN receptor has a separate pathway leading to inhibition of the NF- $\kappa$ B pathway thought to induce DC tolerance [Figure 3]. That said, suppression of the NF- $\kappa$ B pathway is a central anti-inflammatory mechanism that APN utilises [Table 3]. Activation of AdipoR1 results in a IL-10 dependent activation of the STAT3/SOC3 pathway and inhibition of the NF- $\mathrm{BB}$ pathway. A STAT3knockout-DC study demonstrated that STAT3 is essential in developing the IL-10 dependent tolerance ${ }^{[165]}$. 
Table 2. Effect of APN on the immune system

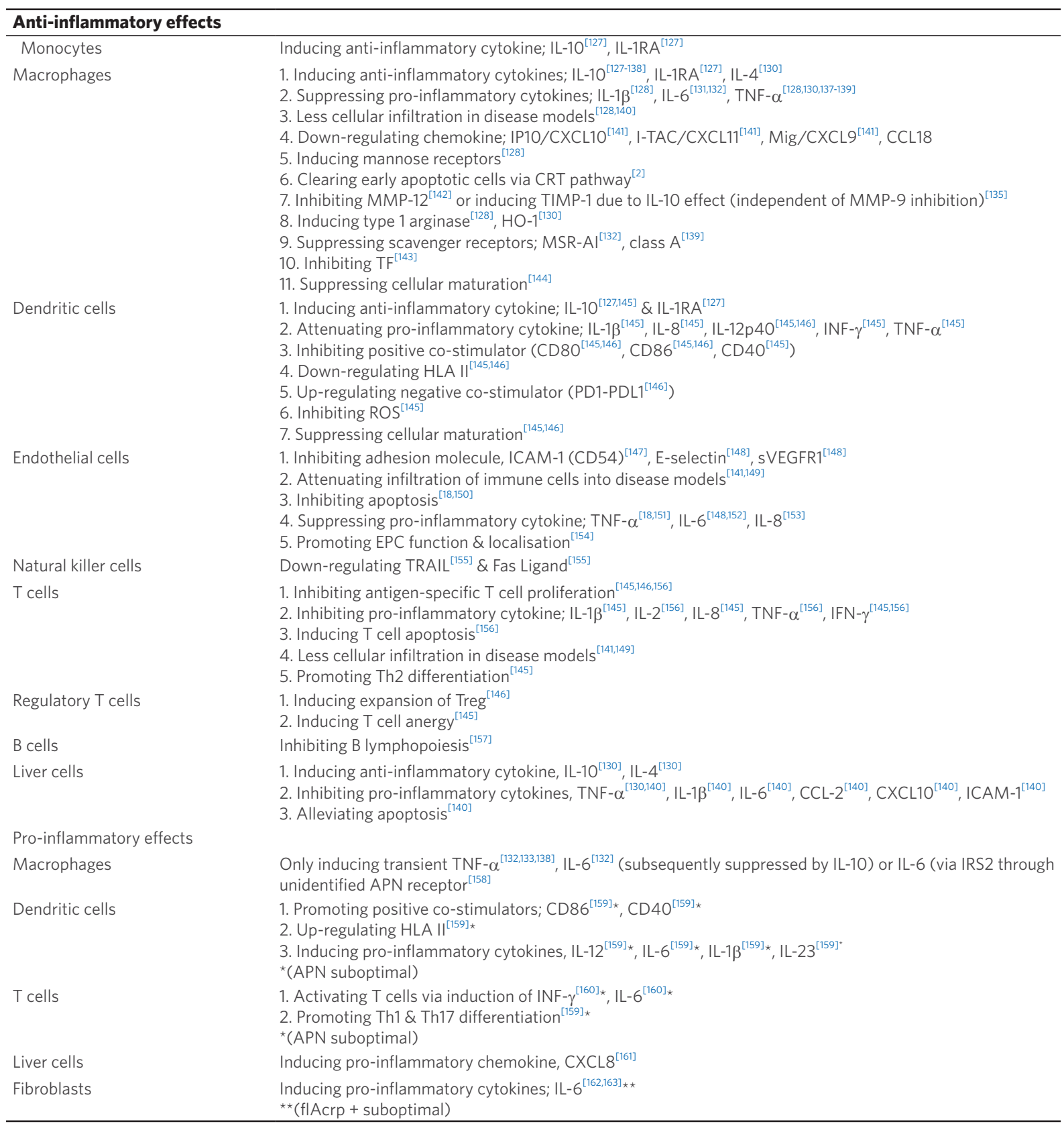

This table summarizes the controversies surrounding the role of APN on the immune system. On balance, majorities of work support the role of APN regulating the immune system negatively. However, the caveats associated with the ability of APN to stimulating the immune system are also demonstrated (as per discussed in the text). The body of evidence on this area tends pale into insignificance comparing to the large experimental data supporting the notion of APN as an immune modulator. IRS-2: insulin receptor substrate-2; ROS: radical oxygen species; C/EBP $\alpha$ : CCAAT/enhancer binding protein-alpha; MCP-1: monocyte chemoattractant protein-1; EPC: endothelial progenitor cell; eNOS: endothelial nitric oxide synthase; IP-10: interferon (IFN)-inducible protein-10; I-TAC: IFN-inducible T cell alpha chemoattractant; Mig: monokine induced by IFN $\gamma$, M1 markers (TNF- $\alpha$, IL-6, MCP-1), CRT/CD91; CRT: calrecticulin; HO-1: heme oxygenase-1; TF: tissue factor; Treg: regulatory T cells

Despite STAT3 being recognised as the dominant mediator for IL-10 functions, this pathway can mediate anti-inflammatory effects in an IL-10 independent manner ${ }^{[166]}$. This includes downstream activation of ETS family transcriptional repressor, ETV3 and a helicase family corepressor, Strawberry notch homologue 2 (SBNO2) that can inhibit NF- $\kappa$ B activation ${ }^{[167]}$. 


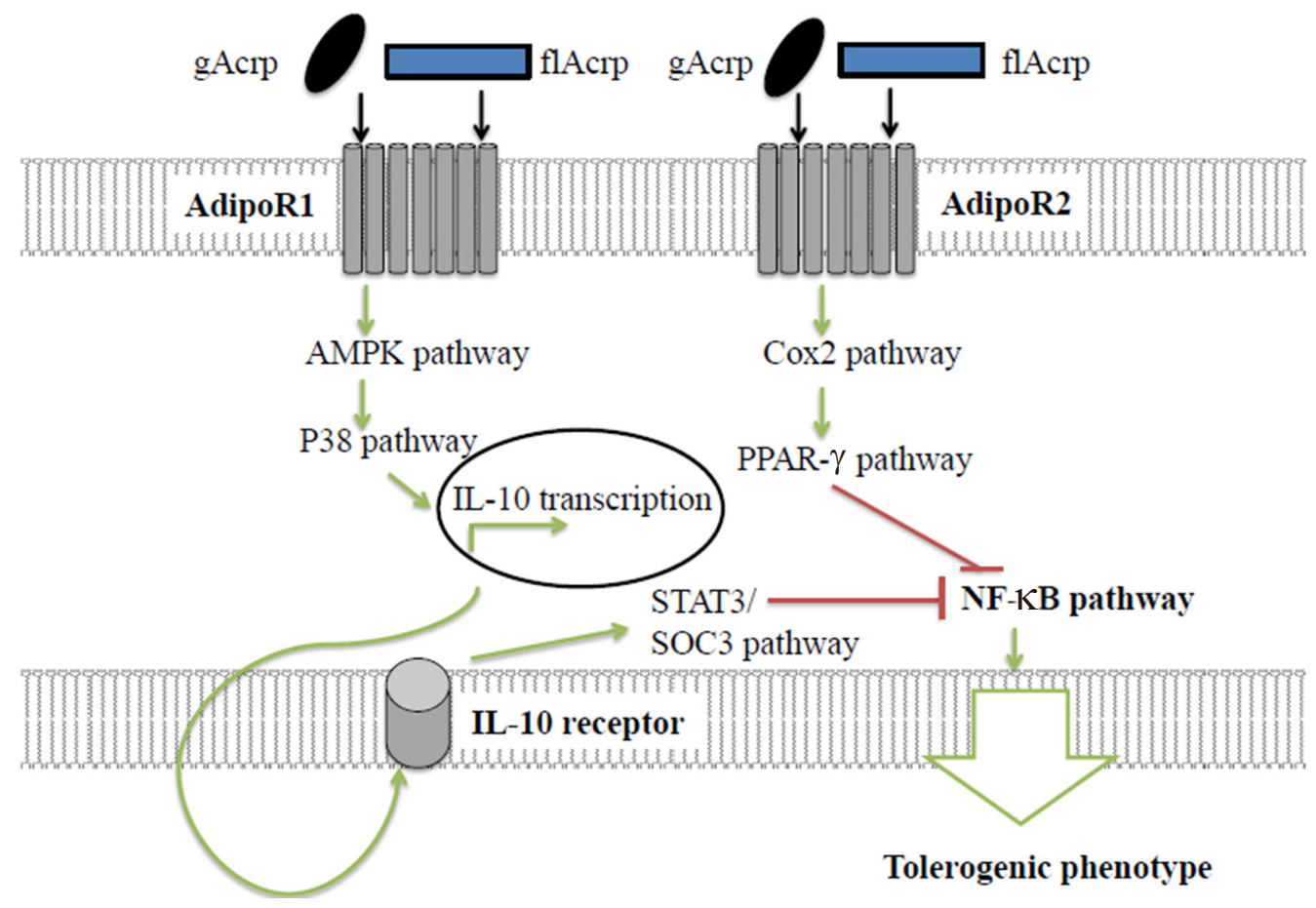

Figure 3. AdipoR1 and AdipoR2 mediated tolerance of dendritic cells. APN generates dendritic cell tolerance via two distinct pathways that converge upon NF- $\mathrm{KB}$ inhibition. Green arrows represent activating pathways. Red lines represent inhibitory pathways. gAcrp: globular adiponectin; flAcrp: full length adiponectin; AMPK: 5' APM activated protein kinase; Cox2: cyclooxygenase-2; PPAR- $\gamma$ : peroxisome proliferator-activated receptor gamma; NF-КB: nuclear factor kappa-light-chain-enhancer of activated B cells; STAT3: signal transducer and activator of transcription 3; SOC3: suppressor of cytokine signalling 3

The second distinct tolerogenic pathway is activated through AdipoR2 [Figure 3]. In AdipoR1-depleted DCs, use of IL-10 receptor antibodies had no effect on the DCs ability to induce T-cell tolerance - suggesting this is a IL-10 independent tolerance process. Instead, the COX-2 pathway upregulates peroxisome proliferatoractivated receptors- $\gamma(\operatorname{PPAR} \gamma)$, inhibiting the NF- $\kappa \mathrm{B}$ pathway, and promoting anergic phenotypes on engaging $\mathrm{T}$ cells ${ }^{[117]}$. After DCs interact with allogenic $\mathrm{T}$ cells the PPAR $\gamma$ pathway drives Th2-cytokine production. Treating DCs with PPAR $\gamma$ agonists produced similar responses ${ }^{[176]}$. DCs with a more dominant AdipoR2 signalling produced significantly more Th2-skewing cytokine production than AdipoR1dominant $\mathrm{DCs}^{[177]}$. It is thought that the SOCS3 pathway may cause the smaller AdipoR1-dependent Th2cytokine production ${ }^{[177]}$. The role of PPAR $\gamma$ is further confirmed through a PPAR $\gamma$-knockout model that prevented tolerance developing ${ }^{[117]}$. It was thought that downstream NF- $\kappa \mathrm{B}$ effectors may contribute towards T-cell tolerance. However, inhibiting anti-NF- $\mathrm{KB}$ effectors was unable to prevent DC promotion of T-cell anergy ${ }^{[117]}$. These studies demonstrate AdipoR1/R2 pathways that enable DC-tolerance and allow cancer evade the immune system.

The role of T-cadherin and APN on the immune system is less known. One proposed mechanism is immune modulation through the enhancement of exosome biogenesis and secretion ${ }^{[124]}$. When exomes are released from a cell, this may protect cells by modulating the immune function of recipient cells ${ }^{[178]}$, or stimulating repair of neighbouring cells ${ }^{[179]}$.

One study showed that T-cadherin is upregulated on chronic cold exposure, enabling APN to be recruited to M2 macrophage cell surface, and promote macrophage proliferation ${ }^{[180]}$. Activation of browning and thermogenesis via this pathway may be a further mechanism that APN uses to protect from metabolic stress. Interestingly, in an AdipoR1 and AdipoR2 depleted system, APN-induced T-cell anergy was reversed, suggesting that T-cadherin mediated APN signalling is unlikely to contribute to this process ${ }^{[117]}$. 
Table 3. Molecular signalling of APN on the immune system and its implication

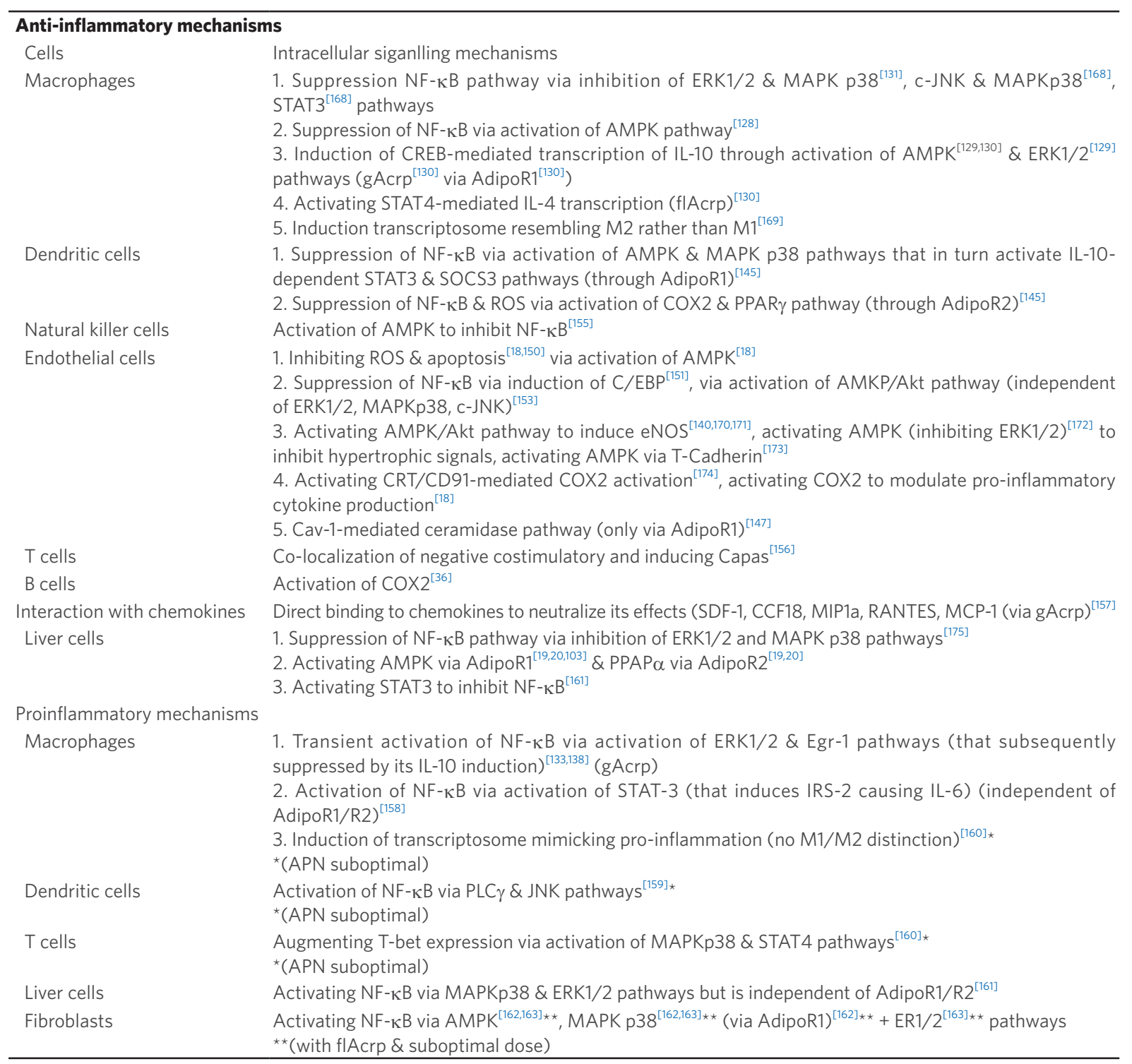

Summary for the molecular mechanism associated with the effect on APN in the immune system is presented here. Current evidence support many molecular pathways are triggered by the APN and its receptors to regulate various arms of the immune system. APN can negatively affect both innate and adaptive immunities. Again, some mechanism on how it can stimulate the immune system is also demonstrated. M2 markers (IL-10, arginase-1, macrophage galactose N-acetyl-galactosamine specific lectin-1). Cav-1: caoveolin-1; SDF-1: stromal cell derived factor-1; MIP-1alpha: macrophage-inflammatory protein-1alpha; MCP-1: monocyte chemoattractant protein-1

APN has the ability to polarise macrophages towards a M2 anti-inflammatory rather than a M1 proinflammatory phenotype [Figure 4]. The administration of APN stimulated expression of M2 markers and reduced expression of M1 markers in human macrophages and adipose tissue ${ }^{[169]}$. APN mediated macrophage polarisation is thought to occur in a IL-10 dependent manner ${ }^{[127,129,131,135,138,169,181,182]}$. The gAcrp and flAcrp polarise macrophages by using separate signalling pathways. The gAcrp stimulates CREB that results in an IL-10 mediated M2 polarisation ${ }^{[129]}$. Whereas, flAcrp utilizes a IL-4/STAT6-dependent mechanism ${ }^{[182]}$. One study demonstrated that flAcrp, through AdipoR2, greatly polarised macrophages to an M2 phenotype. Whereas, gAcrp signalling via the AdipoR2, was much less effective at polarising to the M2 phenotype ${ }^{[182]}$.

There is significant evidence showing that APN can suppress pro-inflammatory cytokines including TNF- $\alpha$, IL-1B, IL-6 [Table 2]. Multiple studies have linked APNs anti-inflammatory effects to TNF- $\alpha$ suppression. 


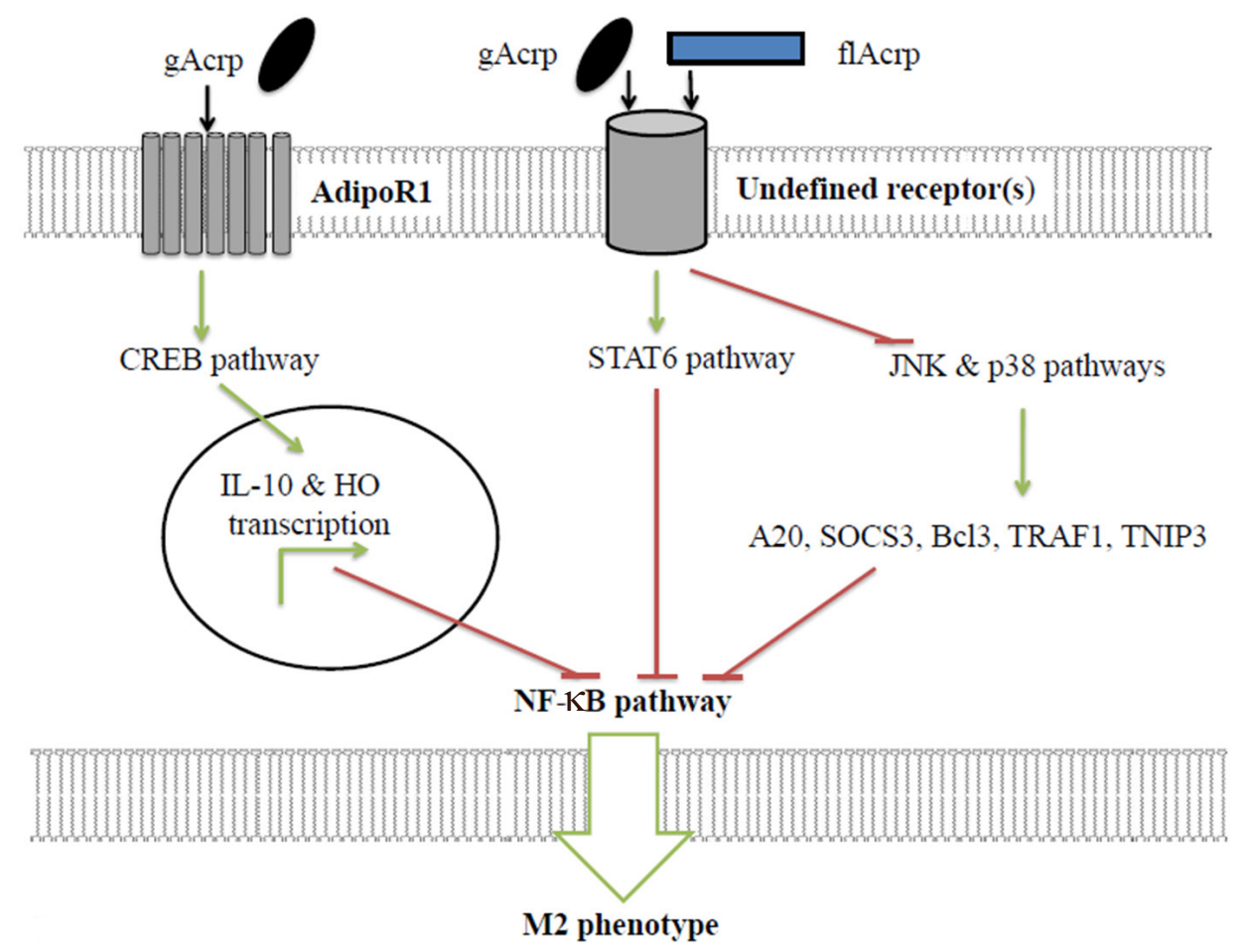

Figure 4. APN-mediated polarisation of macrophages to anti-inflammatory M2 phenotype. Through AdipoR1 and undefined receptors APN causes NF- $\kappa B$ inhibition and promotion of M2 phenotype. Green arrows represent activating pathways. Red lines represent inhibitory pathways. gAcrp: globular adiponectin; fIAcrp: full length adiponectin; STAT6: signal transducer and activator of transcription 6; CREB: cAMP response element-binding protein; JNK: c-Jun N-terminal kinase; SOC3: suppressor of cytokine signalling 3; Bcl3: B-cell lymphoma 3-encoded protein; TRAF1: TNF receptor-associated factor 1; TNIP3: TNFAIP3-interacting protein 3; NF-אB: nuclear factor kappa-lightchain-enhancer of activated $B$ cells

APN-knockout mice showed high levels of TNF- $\alpha$ in both plasma and adipose tissue ${ }^{[5]}$. APN also inhibits a TNF- $\alpha$ induced adhesion molecule ${ }^{[183]}$ which was found to be in high expression in APN-knockout mice ${ }^{[184]}$. Using a reperfusion model, administration of APN reduced apoptosis and TNF- $\alpha$ expression via AMPK and COX-2 respectively ${ }^{[18]}$. However, certain studies have shown that APN causes a rise in TNF- $\alpha^{[181,185]}$. The initial increase in TNF- $\alpha$ is mediated by the ERK1/2 pathway which activates early-growth response protein-1 and via a NF- $\kappa$ B-dependent pathway. Despite an initial rise in TNF- $\alpha$, it leads to an increased expression of IL-10, eventually shifting the system from a pro- to anti-inflammatory state ${ }^{[185]}$.

Other studies have identified further pro-inflammatory effects of APN [Table 2]. One study demonstrated that through an unidentified APN receptor, APN increased IL- 6 production through NF- $\kappa B$ activation ${ }^{[158]}$. APN was again shown to activate the NF- $\mathrm{BB}$ pathway via phospholipase C (PLC)-y and the c-Jun N-terminal Kinase (JNK) pathway ${ }^{[186]}$. This lead to DC activation and enhanced Th1 and Th17 responses. In adult rat cardiac fibroblasts, gAcrp activation of AdipoR1 induced IL-6 synthesis and release through AMPK, p38MAPK, and ERK1/2 pathways ${ }^{[163]}$. However, through AdipoR1 signalling, A20 (zinc finger protein) and B-cell lymphoma 3-encoded protein (Bcl3) upregulation can counter-inhibit IL-6 signalling induced by $\mathrm{APN}^{[117,168]}$. This complicates the overall picture of APN as an anti-inflammatory cytokine, but likely reflects the complex homeostatic mechanisms that are occurring. Although some evidence suggests APNs pro-inflammatory nature, the overwhelming evidence across a number of cell lines suggest to the contrary [Table 2].

An important consideration in whether APN exerts pro- or anti-inflammatory properties is the concentration that is used in studies. The physiological level of APN in a non-obese, non-diabetic patient is $\sim 10 \mu \mathrm{g} / \mathrm{mL}^{[187]}$. When conditioning immune cells, we must take into consideration the concentration of APN used. In certain systems, when the conditioning of immune cells was done at physiological levels, the 
opposite effect occurred ${ }^{[188]}$. Therefore, the concentration of APN used for conditioning may greatly change the outcome of a study.

Many of the studies showing APN having pro-inflammatory effects used concentrations of $\sim 10 \mu \mathrm{g} / \mathrm{mL}^{[160,186]}$. A recent study demonstrated that approximately a plasma APN concentration of $40 \mu \mathrm{g} / \mathrm{mL}$ was needed to induce IL-10 production and an anti-inflammatory response ${ }^{[117]}$. Furthermore, physical exercise can increase APN by $260 \%$ off baseline ${ }^{[189]}$. Therefore, it may be unlikely that using a physiological level of APN would result in the desired anti-inflammatory effects due to sub-optimal signalling.

Interpreting APNs role on immune cells is further complicated as the kinetics of AdipoR1/R2 differ depending on the specific immune cell and stage of differentiation. Expression of AdipoR1/R2 occurs in $80 \%-90 \%$ of $\mathrm{CD}_{14}{ }^{+}$, compared to $10 \%$ of T-cells ${ }^{[156]}$. As monocytes differentiate into macrophages AdipoR 1 expression decreases, whereas AdipoR2 expression is constant ${ }^{[190]}$. Likewise, the presence of various APN oligomers and the multitude of signalling differences make it hard to pinpoint APNs exact role. For example, differences are observed between HMW APN and gAcrp inhibition of the NF- $\kappa$ B pathway ${ }^{[191]}$. HMW APN required shorted incubation period to inhibit NF- $\kappa B$ compared with gAcrp. While gAcrp produces a transient activation and requires a longer incubation period to inhibit the pathway ${ }^{[191]}$.

In the adaptive immune system APN has been shown to act as a negative regulator for T-cells ${ }^{[156]}$ and affect the migration of T-cells towards diseased tissue ${ }^{[141,149]}$. Although only $10 \%$ of T-cells express AdipoR1/R2 on their surface, the majority of T-cells store these receptors within intracellular clathrin-coated vesicles. After stimulation, T-cells upregulate these receptors on the surface and APN interaction subsequently enhances apoptosis and inhibits proliferation. In APN-deficient mice, infection lead to a significantly higher number of $\mathrm{CD}_{137^{+}} \mathrm{T}$ cells ${ }^{[156]}$. Furthermore, culturing APN-DCs with allogenic T-cells decreased T-cell proliferation and pro-inflammatory cytokine production ${ }^{[146]}$. A rise in regulatory T-cells was also identified, providing an alternative mechanism that APN can regulate the immune system ${ }^{[146]}$. With regard to migration, APN can inhibit expression of chemokines that act as T-cell chemoattractants in atherogenesis ${ }^{[141]}$. Therefore, when APN levels are low in cancer, this could favour T-cell recruitment, and contribute towards adaptive immune response. Lastly, one study suggested that rather than affecting proliferation, APN directly activates $\mathrm{CD}^{+}{ }^{+}$T-cells and increases secretion of interferon- $\gamma$ and IL- $6^{[160]}$. It is thought that this inflammatory activation likely desensitises the cells to further pro-inflammatory stimuli. That said, this study uses a low concentration of APN which may influence our interpretation of the results.

\section{FUTURE IMPLICATIONS OF INTERFERING WITH THE APN PATHWAY ON CANCER TREATMENT}

It is clear that APN has the ability to alter cancer outcomes, biology, and anti-cancer immunity. Therefore, APN has been identified as a therapeutic and preventive target for cancer therapy. The pleiotropic nature of various APN isoforms has caused trouble initially engineering an APN analogue, consequently groups decided to screen for endogenous agonists or enhancing existing APN levels.

The first APN receptor agonist screened for and produced was ADP355 ${ }^{[192]}$. ADP355 binds both AdipoR1/ $\mathrm{R} 2$, with a greater affinity to AdipoR ${ }^{[192]}$. In vivo, this agonist inhibited orthotopic human $\mathrm{BC}$ xenograft growth by $31 \%$, with an acceptable safety profile. Similar to gAcrp, ADP355 regulated signalling pathways AMPK, STAT3, PIK3/Akt, and ERK1/2. The group was able to improve agonistic activity by 5-10 fold by substituting Gly4 and Tyr7 residues with Pro and Hyp respectively ${ }^{[193]}$. High-throughput screening identified several endogenous adiponectin ligands: AdipoR1 agonists included matairesinol, arctiin, (-)-arctigenin and gramine, while AdipoR2 agonists included parthenolide, taxifoliol, deoxyschizandrin, and syringing ${ }^{[194]}$. Further studies identified AdipoRon as a strong AdipoR1/R2 agonist at low micromolar concentrations, signalling through AMPK and PPAR- $\alpha$ pathways ${ }^{[195]}$. 
An alternative proposed method is to augment endogenous APN levels using PPAR $\gamma$ ligands ${ }^{[196]}$. Using synthetic PPAR ligands, one group demonstrated that expression and secretion of APN increased in a dose and time dependent manner ${ }^{[197]}$. Efatutazone, a selective PPAR $\gamma$ agonist, showed promise on a phase I trial in metastatic solid tumours ${ }^{[198]}$, metastatic colorectal cancer ${ }^{[199]}$, and thyroid cancer patients ${ }^{[200]}$. However, trials were terminated after phase 2 due to insufficient efficacy ${ }^{[201,202]}$.

Another PPAR $\gamma$ agonist Troglitazone has gained much attention in recent years. Troglitazone has been shown to inhibit migration and invasion in human prostate cancer cells ${ }^{[203]}$, inhibit matrix metalloproteinase-9 expression and invasion of breast cancer cells ${ }^{[204]}$, and have anti-tumour effects without marked adverse effects $^{[205]}$. One study showed that Troglitazone mediated PPAR $\gamma$ activation enhances human lung cell cancer cells to TRIAL-induced apoptosis ${ }^{[206]}$. Suggesting that if used in combination with TRIAL protein it could be useful against TRIAL-resistant cancer cells. That said, phase II studies in refractory breast cancer ${ }^{[207]}$ and metastatic colorectal cancer ${ }^{[208]}$ have had disappointing results. A synthetic derivative of Troglitazone, $\Delta 2-$ Troglitazone was shown to be more potent in reducing cancer cell proliferation, however no clinical value has been found ${ }^{[209]}$.

Rosiglitazone, a PPAR $\gamma$ agonist, has been shown to have beneficial effects on atherosclerosis, insulin resistance, and type 2 diabetes ${ }^{[210,211]}$. However, a phase II trial using Rosiglitazone in liposarcoma patients concluded that this agonist was not an effective anti-tumour drug ${ }^{[212]}$. It is important to highlight the side-effect profile of these trial drugs. Rosiglitazone has been shown to increase risk of cardiovascular disease $^{[213]}$ and Troglitazone presents concerns regarding hepatotoxicity ${ }^{[207]}$. Additional cautions should be taken with chronically elevated APN levels which can be linked to infertility and reduced bone density ${ }^{[214]}$. Furthermore, interfering with the AdipoR1/R2 pathways can have adverse effects for anti-tumour immune response $^{[145]}$, consequently a fine balance must be achieved to ensure the anti-cancer pathways are promoted.

With there being limited success with current therapeutic agents one current use for APN is as prognostic markers for cancer ${ }^{[215]}$. Both serum APN levels, the expression of AdipoR1/R2, and SNPs could all provide avenues for prognostic and predictive molecular tests in cancer. A number of SNPs in ADIPOQ or APNs receptors have been found associated with $\mathrm{BC}, \mathrm{CRC}, \mathrm{EC}, \mathrm{GC}, \mathrm{PC}, \mathrm{HC}, \mathrm{RCC}, \mathrm{PrC}$, and $\mathrm{LC}^{[65]}$. The question arises whether there would be any change in clinical decision making through screening these SNPs or whether they would give any benefit above currently used biomarkers. That said, if well targeted, these tests could help early diagnosis, aid post-operative recovery, and initiate APN modulatory therapy

It has been shown that a Mediterranean-type diet, reduction in body weight, and exercise can increase circulating APN levels ${ }^{[189,216]}$. Furthermore, aerobic exercise was shown to increase expression of AdipoR1 and AdipoR2 in young men ${ }^{[217]}$. Therefore, using programmes that promote weight loss and a healthy diet in parallel with new APN promoting agents may enable more favourable outcome. Similarly, new APN therapeutic agents may show more promise when being used in combination with traditional treatment by sensitising cancer cells.

A number of cancers are strongly associated with chronic inflammatory processes, for example the association between inflammatory bowel disease and CRC, or Helicobacter pylori infection and GC ${ }^{[218]}$. These type of cancers could greatly benefit from the anti-inflammatory properties of APN. In cancer there is often defective inflammatory responses, the goal is to restore the normal overall host response, without undesirable side effects. However, one needs to acknowledge that by altering these metabolic pathways there is a chance of detrimental changes to anti-tumour immunity. Moreover, as carcinogenesis progresses, there are changes to the way the tumour environment harnesses the immune system, therefore the timing of treatment may greatly alter the efficacy.

When considering APN as a therapeutic agent it is important to highlight several points. Firstly, many factors influence the levels of circulating APN. Sex, age, ethnicity, and intra-abdominal fat all have 
independent roles in determining APN levels ${ }^{[219]}$. This is important to consider as a therapeutic agent may have greatly differing effects across individuals. Secondly, the pleomorphic nature of APNs isoforms mean it will be hard to replicate each isoforms action. One option would be to use recombinant APN, however this has been difficult to produce and would be expensive over the long term. The solution has been to attempt to increase endogenous APN, but we must consider whether it may be beneficial to selectively increase one isoform. Thirdly, the dosage APN used can affect the inflammatory response in a varied manner. In creating a novel agent, the dose regime must be carefully designed to ensure the desired response is seen.

\section{CONCLUSION}

Obesity related-cancers are now a recognised phenomenon. APN is the key adipokine produced by the fat cells and its role in cancer pathogenesis and disease prognosis is now slowly revealed. Hypoadiponectinaemia is often found to be associated with cancers and also affects their prognosis. Therefore, various efforts have been made to harness its therapeutic effects. It can be applied either therapeutically or prophylactically to treat various cancers. For example, identification of ADIPOQ, AdipoR1 and AdipoR2 SNPs that may confer altered risks of cancer development may enable early screening and APN level augmentation via therapeutic interventions.

Overall this field holds a huge promise, however many challenges will need to be addressed prior to its routine use. Cellular and molecular function of APN in cancer either its pathogenesis phase or advanced forms of cancer will need to be fully researched. APN may have different effect on various stages of cancers either directly or indirectly via immune system. The role of each isoform in distinct tissues and under specific conditions needs be clarified. More importantly, the molecular conditions under which APN acts as cancer suppressing or promoting and anti-inflammatory or pro-inflammatory still needs to be fully evaluated. The exact roles of APN interacting which receptors (some identified but some remained to be defined) and their downstream pathways in different cancer have largely remained elusive. Exploring an effective APN-based therapeutic and when to applied this therapeutic may be the crucial step. Understanding the complexity of APN on anti-tumour response may need to be considered when using it as a therapeutic agent.

\section{DECLARATIONS}

\section{Acknowledgments}

Due to the space restrictions, the authors were able to cite only a fraction of the relevant literature. We apologize to any colleagues whose contribution might not be appropriately acknowledged in this review.

\section{Authors' contributions}

Wrote and prepared most of the manuscript: Monks M

Contributed toward the revision of manuscript: Irakleidis F

Provided guidance and mentorship to all authors in writing and revising the manuscript: Tan $\mathrm{PH}$

\section{Availability of data and materials}

Not applicable.

\section{Financial support and sponsorship}

Tan PH is funded by Royal Free NHS Foundation Trust as a full-time Consultant Oncoplastic Breast Surgeon.

\section{Conflicts of interest}

All authors declared that there are no conflicts of interest.

\section{Ethical approval and consent to participate}

Not applicable. 


\section{Consent for publication}

Not applicable.

\section{Copyright}

(c) The Author(s) 2019.

\section{REFERENCES}

1. Kershaw EE, Flier JS. Adipose tissue as an endocrine organ. J Clin Endocrinol Metab 2004;89:2548-56.

2. Takemura Y, Ouchi N, Shibata R, Aprahamian T, Kirber MT, et al. Adiponectin modulates inflammatory reactions via calreticulin receptordependent clearance of early apoptotic bodies. J Clin Invest 2007;117:375-86.

3. van Stijn CM, Kim J, Barish GD, Tietge UJ, Tangirala RK. Adiponectin expression protects against angiotensin II-mediated inflammation and accelerated atherosclerosis. PLoS One 2014;9:e86404.

4. Yamauchi T, Kamon J, Ito Y, TsuchLabela A, Yokomizo T, et al. Cloning of adiponectin receptors that mediate antLabeliabetic metabolic effects. Nature 2003;423:762-9.

5. Maeda N, Shimomura I, Kishida K, Nishizawa H, Matsuda M, et al. Diet-induced insulin resistance in mice lacking adiponectin/ACRP30. Nat Med 2002;8:731-7.

6. Khandekar MJ, Cohen P, Spiegelman BM. Molecular mechanisms of cancer development in obesity. Nat Rev Cancer 2011;11:886-95.

7. Scherer PE, Williams S, Fogliano M, Baldini G, Lodish HF. A novel serum protein similar to C1q, produced exclusively in adipocytes. J Biol Chem 1995;270:26746-9.

8. Shapiro L, Scherer PE. The crystal structure of a complement-1q family protein suggests an evolutionary link to tumor necrosis factor. Curr Biol 1998;8:335-40.

9. Wang Y, Lam KSL, Yau M, Xu A. Post-translational modifications of adiponectin: mechanisms and functional implications. Biochem J 2008;409:623-33.

10. Fujimoto N, Matsuo N, Sumiyoshi H, Yamaguchi K, Saikawa T, et al. Adiponectin is expressed in the brown adipose tissue and surrounding immature tissues in mouse embryos. Biochim Biophys Acta - Gene Struct Expr 2005;1731:1-12.

11. Kusminski CM, McTernan PG, Schraw T, Kos K, O’Hare JP, et al. Adiponectin complexes in human cerebrospinal fluid: distinct complex distribution from serum. Diabetologia 2007;50:634-42.

12. Piñeiro R, Iglesias MJ, Gallego R, Raghay K, Eiras S, et al. Adiponectin is synthesized and secreted by human and murine cardiomyocytes. FEBS Lett 2005;579:5163-9.

13. Delaigle AM, Jonas JC, Bauche IB, Cornu O, Brichard SM. Induction of adiponectin in skeletal muscle by inflammatory cytokines: in vivo and in vitro studies. Endocrinology 2004;145:5589-97.

14. Kaser S, Moschen A, Cayon A, Kaser A, Crespo J, et al. Adiponectin and its receptors in non-alcoholic steatohepatitis. Gut 2005;54:117-21.

15. Yokota T, Meka CS, Medina KL, Igarashi H, Comp PC, et al. Paracrine regulation of fat cell formation in bone marrow cultures via adiponectin and prostaglandins. J Clin Invest 2002;109:1303-10.

16. Suzuki S, Wilson-Kubalek EM, Wert D, Tsao TS, Lee DH. The oligomeric structure of high molecular weight adiponectin. FEBS Lett NIH Public Access2007;581:809-14.

17. Katira A, Tan PH. Adiponectin and its receptor signaling: an anti-cancer therapeutic target and its implications for anti-tumor immunity. Expert Opin Ther Targets 2015;19:1105-25.

18. Shibata R, Sato K, Pimentel DR, Takemura Y, Kihara S, et al. Adiponectin protects against myocardial ischemia-reperfusion injury through AMPK- and COX-2-dependent mechanisms. Nat Med 2005;11:1096-103.

19. Yamauchi T, Kamon J, Ito Y, Tsuchida A, Yokomizo T, et al. Cloning of adiponectin receptors that mediate antidiabetic metabolic effects. Nature 2003;423:762-9.

20. Yamauchi T, Nio Y, Maki T, Kobayashi M, Takazawa T, et al. Targeted disruption of AdipoR1 and AdipoR2 causes abrogation of adiponectin binding and metabolic actions. Nat Med 2007;13:332-9.

21. Hebbard LW, Garlatti M, Young LJT, Cardiff RD, Oshima RG, et al. T-cadherin supports angiogenesis and adiponectin association with the vasculature in a mouse mammary tumor model. Cancer Res 2008;68:1407-16.

22. Brochu-Gaudreau K, Rehfeldt C, Blouin R, Bordignon V, Murphy BD, et al. Adiponectin action from head to toe. Endocrine 2010;37:11-32.

23. Hug C, Wang J, Ahmad NS, Bogan JS, Tsao TS, et al. T-cadherin is a receptor for hexameric and high-molecular-weight forms of Acrp30/ adiponectin. Proc Natl Acad Sci 2004;101:10308-13.

24. Xu XT, Xu Q, Tong JL, Zhu MM, Huang ML, et al. Meta-analysis: circulating adiponectin levels and risk of colorectal cancer and adenoma. J Dig Dis 2011;12:234-44.

25. Joshi RK, Kim WJ, Lee SA. Association between obesity-related adipokines and colorectal cancer: a case-control study and meta-analysis. World J Gastroenterol 2014;20:7941.

26. An W, Bai Y, Deng SX, Gao J, Ben QW, et al. Adiponectin levels in patients with colorectal cancer and adenoma. Eur J Cancer Prev 2012;21:126-33.

27. Wei EK, Giovannucci E, Fuchs CS, Willett WC, Mantzoros CS. Low plasma adiponectin levels and risk of colorectal cancer in men: a prospective study. J Natl Cancer Inst 2005;97:1688-94.

28. Song M, Zhang X, Wu K, Ogino S, Fuchs CS, et al. Plasma adiponectin and soluble leptin receptor and risk of colorectal cancer: a prospective study. Cancer Prev Res (Phila) 2013;6:875-85.

29. Ferroni P, Palmirotta R, Spila A, Martini F, Raparelli V, et al. Prognostic significance of adiponectin levels in non-metastatic colorectal cancer. Anticancer Res 2007;27:483-9. 
30. Gialamas SP, Petridou ET, Tseleni-Balafouta S, Spyridopoulos TN, Matsoukis IL, et al. Serum adiponectin levels and tissue expression of adiponectin receptors are associated with risk, stage, and grade of colorectal cancer. Metabolism 2011;60:1530-8.

31. Fujisawa T, Endo H, Tomimoto A, Sugiyama M, Takahashi H, et al. Adiponectin suppresses colorectal carcinogenesis under the high-fat diet condition. Gut 2008;57:1531-8.

32. Nagaraju GP, Aliya S, Alese OB. Role of adiponectin in obesity related gastrointestinal carcinogenesis. Cytokine Growth Factor Rev 2015;26:83-93.

33. Vetvik KK, Sonerud T, Lindeberg M, Lüders T, Størkson RH, et al. Globular adiponectin and its downstream target genes are up-regulated locally in human colorectal tumors: ex vivo and in vitro studies. Metabolism 2014;63:672-81.

34. Tsukada T, Fushida S, Harada S, Terai S, Yagi Y, et al. Adiponectin receptor-1 expression is associated with good prognosis in gastric cancer. J Exp Clin Cancer Res 2011;30:107.

35. Wu X, Chen P, Ou Y, Liu J, Li C, et al. Association of variants on ADIPOQ and AdipoR1 and the prognosis of gastric cancer patients after gastrectomy treatment. Mol Biol Rep 2015;42:355-61.

36. Yamamoto H, Maeda K, Uji Y, Tsuchihashi H, Mori T, et al. Association between Reduction of Plasma Adiponectin Levels and Risk of Bacterial Infection after Gastric Cancer Surgery. PLoS One 2013;8:e56129.

37. Howard JM, Cathcart MC, Healy L, Beddy P, Muldoon C, et al. Leptin and adiponectin receptor expression in oesophageal cancer. Br J Surg 2014;101:643-52.

38. Rubenstein JH, Kao JY, Madanick RD, Zhang M, Wang M, et al. Association of adiponectin multimers with Barrett's oesophagus. Gut 2009;58:1583-9

39. Ye J, Jia J, Dong S, Zhang C, Yu S, et al. Circulating adiponectin levels and the risk of breast cancer. Eur J Cancer Prev 2014;23:158-65.

40. Körner A, Pazaitou-Panayiotou K, Kelesidis T, Kelesidis I, Williams CJ, et al. Total and high-molecular-weight adiponectin in breast cancer: in vitro and in vivo studies. J Clin Endocrinol Metab 2007;92:1041-8.

41. Shahar S, Salleh RM, Ghazali AR, Koon PB, Mohamud WN. Roles of adiposity, lifetime physical activity and serum adiponectin in occurrence of breast cancer among Malaysian women in Klang Valley. Asian Pac J Cancer Prev 2010;11:61-6.

42. Miyoshi Y, Funahashi T, Kihara S, Taguchi T, Tamaki Y, et al. Association of serum adiponectin levels with breast cancer risk. Clin Cancer Res 2003;9:5699-704.

43. Chen DC, Chung YF, Yeh YT, Chaung HC, Kuo FC, et al. Serum adiponectin and leptin levels in Taiwanese breast cancer patients. Cancer Lett 2006;237:109-14.

44. Oh SW, Park CY, Lee ES, Yoon YS, Lee ES, et al. Adipokines, insulin resistance, metabolic syndrome, and breast cancer recurrence: a cohort study. Breast Cancer Res 2011;13:R34.

45. Gaudet MM, Falk RT, Gierach GL, Lacey JV, Graubard BI, et al. Do adipokines underlie the association between known risk factors and breast cancer among a cohort of United States women? Cancer Epidemiol 2010;34:580-6.

46. Nagaraju GP, Rajitha B, Aliya S, Kotipatruni RP, Madanraj AS, et al. The role of adiponectin in obesity-associated female-specific carcinogenesis. Cytokine Growth Factor Rev 2016;31:37-48.

47. Zheng Q, Wu H, Cao J. Circulating adiponectin and risk of endometrial cancer. PLoS One 2015;10:e0129824.

48. Dal Maso L, Augustin LS, Karalis A, Talamini R, Franceschi S, et al. Circulating adiponectin and endometrial cancer risk. J Clin Endocrinol Metab 2004;89:1160-3.

49. Cong L, Gasser J, Zhao J, Yang B, Li F, et al. Human adiponectin inhibits cell growth and induces apoptosis in human endometrial carcinoma cells, HEC-1-A and RL95-2. Endocr Relat Cancer 2007;14:713-20.

50. Benaitreau D, Dieudonné MN, Dos Santos E, Leneveu MC, Mazancourt Pd, et al. Antiproliferative effects of adiponectin on human trophoblastic cell lines JEG-3 and BeWo1. Biol Reprod 2009;80:1107-14.

51. Ohbuchi Y, Suzuki Y, Hatakeyama I, Nakao Y, Fujito A, et al. A lower serum level of middle-molecular-weight adiponectin is a risk factor for endometrial cancer. Int J Clin Oncol 2014;19:667-73.

52. Stolzenberg-Solomon RZ, Weinstein S, Pollak M, Tao Y, Taylor PR, et al. Prediagnostic adiponectin concentrations and pancreatic cancer risk in male smokers. Am J Epidemiol 2008;168:1047-55.

53. Dalamaga M, Migdalis I, Fargnoli JL, Papadavid E, Bloom E, et al. Pancreatic cancer expresses adiponectin receptors and is associated with hypoleptinemia and hyperadiponectinemia: a case-control study. Cancer Causes Control 2009;20:625-33.

54. Grote VA, Rohrmann S, Dossus L, Nieters A, Halkjaer J, et al. The association of circulating adiponectin levels with pancreatic cancer risk: a study within the prospective EPIC cohort. Int J Cancer 2012;130:2428-37.

55. Kenner BJ, Go VLW, Chari ST, Goldberg AE, Rothschild LJ. Early detection of pancreatic cancer: the role of industry in the development of biomarkers. Pancreas 2017;46:1238-41.

56. Spyridopoulos TN, Petridou ET, Skalkidou A, Dessypris N, Chrousos GP, et al. Low adiponectin levels are associated with renal cell carcinoma: a case-control study. Int J Cancer 2007;120:1573-8.

57. Pinthus JH, Kleinmann N, Tisdale B, Chatterjee S, Lu JP, et al. Lower plasma adiponectin levels are associated with larger tumor size and metastasis in clear-cell carcinoma of the kidney. Eur Urol 2008;54:866-74.

58. Horiguchi A, Ito K, Sumitomo M, Kimura F, Asano T, et al. Decreased serum adiponectin levels in patients with metastatic renal cell carcinoma. Jpn J Clin Oncol 2008;38:106-11.

59. Liao LM, Schwartz K, Pollak M, Graubard BI, Li Z, et al. Serum leptin and adiponectin levels and risk of renal cell carcinoma. Obesity 2013;21:1478-85.

60. Burton A, Martin RM, Holly J, Lane JA, Donovan JL, et al. Associations of adiponectin and leptin with stage and grade of PSA-detected prostate cancer: the ProtecT study. Cancer Causes Control 2013;24:323-34.

61. Dhillon PK, Penney KL, Schumacher F, Rider JR, Sesso HD, et al. Common polymorphisms in the adiponectin and its receptor genes, adiponectin levels and the risk of prostate cancer. Cancer Epidemiol Biomarkers Prev 2011;20:2618-27.

62. Wang SN, Yang SF, Tsai HH, Lee KT, Yeh YT. Increased adiponectin associated with poor survival in hepatocellular carcinoma. J 
Gastroenterol 2014;49:1342-51.

63. Shin E, Yu YD, Kim DS, Won NH. Adiponectin receptor expression predicts favorable prognosis in cases of hepatocellular carcinoma. Pathol Oncol Res 2014;20:667-75.

64. Petridou ET, Mitsiades N, Gialamas S, Angelopoulos M, Skalkidou A, et al. Circulating adiponectin levels and expression of adiponectin receptors in relation to lung cancer: two case-control studies. Oncology 2007;73:261-9.

65. Katira A, Tan PH. Evolving role of adiponectin in cancer-controversies and update. Cancer Biol Med 2016;13:101-19.

66. Erichsen HC, Chanock SJ. SNPs in cancer research and treatment. Br J Cancer 2004;90:747-51.

67. Erarslan E, Turkay C, Koktener A, Koca C, Uz B, et al. Association of visceral fat accumulation and adiponectin levels with colorectal neoplasia. Dig Dis Sci 2009;54:862-8.

68. Kemik O, Sumer A, Kemik A, Hasirci I, Purisa S, et al. The relationship among acute-phase response proteins, cytokines and hormones in cachectic patients with colon cancer. World J Surg Oncol 2010;8:85.

69. Nakajima TE, Yamada Y, Hamano T, Furuta K, Matsuda T, et al. Adipocytokines as new promising markers of colorectal tumors: adiponectin for colorectal adenoma, and resistin and visfatin for colorectal cancer. Cancer Sci 2010;101:1286-91.

70. Aleksandrova K, Boeing H, Jenab M, Bueno-de-Mesquita HB, Jansen E, et al. Total and high-molecular weight adiponectin and risk of colorectal cancer: the European prospective investigation into cancer and nutrition study. Carcinogenesis 2012;33:1211-8.

71. Lukanova A, Söderberg S, Kaaks R, Jellum E, Stattin P. Serum adiponectin is not associated with risk of colorectal cancer. Cancer Epidemiol Biomarkers Prev 2006;15:401-2.

72. Stocks T, Lukanova A, Johansson M, Rinaldi S, Palmqvist R, et al. Components of the metabolic syndrome and colorectal cancer risk; a prospective study. Int J Obes 2008;32:304-14.

73. Nakajima TE, Yamada Y, Hamano T, Furuta K, Gotoda T, et al. Adipocytokine levels in gastric cancer patients: resistin and visfatin as biomarkers of gastric cancer. J Gastroenterol 2009;44:685-90.

74. Ishikawa M, Kitayama J, Kazama S, Hiramatsu T, Hatano K, et al. Plasma adiponectin and gastric cancer. Clin Cancer Res 2005;11:466-72.

75. Seker M, Bilici A, Sonmez B, Ustaalioğlu BBO, Gumus M, et al. The association of serum adiponectin levels with histopathological variables in gastric cancer patients. Med Oncol 2010;27:1319-23.

76. Yildirim A, Bilici M, Cayir K, Yanmaz V, Yildirim S, et al. Serum adiponectin levels in patients with esophageal cancer. Jpn J Clin Oncol 2008;39:92-6.

77. Duggan C, Onstad L, Hardikar S, Blount PL, Reid BJ, et al. Association between markers of obesity and progression from Barrett's esophagus to esophageal adenocarcinoma. Clin Gastroenterol Hepatol 2013;11:934-43.

78. Nakajima TE, Yamada Y, Hamano T, Furuta K, Oda I, et al. Adipocytokines and squamous cell carcinoma of the esophagus. J Cancer Res Clin Oncol 2010;136:261-6.

79. Diao Y, Li H, Li H, Zhou Y, Ma Q, et al. Association of serum levels of lipid and its novel constituents with the different stages of esophageal carcinoma. Lipids Health Dis 2009;8:48.

80. Mantzoros C, Petridou E, Dessypris N, Chavelas C, Dalamaga M, et al. Adiponectin and Breast Cancer Risk. J Clin Endocrinol Metab 2004;89:1102-7.

81. Duggan C, Irwin ML, Xiao L, Henderson KD, Smith AW, et al. Associations of insulin resistance and adiponectin with mortality in women with breast cancer. J Clin Oncol 2011;29:32-9.

82. Macis D, Gandini S, Guerrieri-Gonzaga A, Johansson H, Magni P, et al. Prognostic effect of circulating adiponectin in a randomized $2 \times 2$ trial of low-dose tamoxifen and fenretinide in premenopausal women at risk for breast cancer. J Clin Oncol 2012;30:151-7.

83. Kang JH, Yu BY, Youn DS. Relationship of serum adiponectin and resistin levels with breast cancer risk. J Korean Med Sci 2007;22:117.

84. Hou WK, Xu YX, Yu T, Zhang L, Zhang WW, et al. Adipocytokines and breast cancer risk. Chin Med J (Engl) 2007;120:1592-6.

85. Tworoger SS, Eliassen AH, Kelesidis T, Colditz GA, Willett WC, et al. Plasma adiponectin concentrations and risk of incident breast cancer. J Clin Endocrinol Metab 2007;92:1510-6.

86. Cust AE, Kaaks R, Friedenreich C, Bonnet F, Laville M, et al. Plasma adiponectin levels and endometrial cancer risk in pre- and postmenopausal women. J Clin Endocrinol Metab 2007;92:255-63.

87. Ma Y, Liu Z, Zhang Y, Lu B. Serum leptin, adiponectin and endometrial cancer risk in Chinese women. J Gynecol Oncol 2013;24:336-41.

88. Bohlouli S, Khazaei M, Teshfam M, Hassanpour H. Adiponectin effect on the viability of human endometrial stromal cells and mRNA expression of adiponectin receptors. Int J Fertil Steril 2013;7:43-8.

89. Bao Y, Giovannucci EL, Kraft P, Stampfer MJ, Ogino S, et al. A prospective study of plasma adiponectin and pancreatic cancer risk in five US cohorts. J Natl Cancer Inst 2013;105:95-103.

90. Chang MC, Chang YT, Su TC, Yang WS, Chen CL, et al. Adiponectin as a potential differential marker to distinguish pancreatic cancer and chronic pancreatitis. Pancreas 2007;35:16-21

91. Krechler T, Zeman M, Vecka M, Macasek J, Jachymova M, et al. Leptin and adiponectin in pancreatic cancer: connection with diabetes mellitus. Neoplasma 2011;58:58-64.

92. Kotani K, Wakai K, Shibata A, Fujita Y, Ogimoto I, et al. Serum adiponectin multimer complexes and liver cancer risk in a large cohort study in Japan. Asian Pac J Cancer Prev 2009;10 Suppl:87-90.

93. Sumie S, Kawaguchi T, Kuromatsu R, Takata A, Nakano M, et al. Total and high molecular weight adiponectin and hepatocellular carcinoma with HCV infection. PLoS One 2011;6:e26840.

94. Li H, Stampfer MJ, Mucci L, Rifai N, Qiu W, et al. A 25-year prospective study of plasma adiponectin and leptin concentrations and prostate cancer risk and survival. Clin Chem 2010;56:34-43.

95. Michalakis K, Williams CJ, Mitsiades N, Blakeman J, Balafouta-Tselenis S, et al. Serum adiponectin concentrations and tissue expression of adiponectin receptors are reduced in patients with prostate cancer: a case control study. Cancer Epidemiol Biomarkers Prev 2007;16:308-13.

96. Arisan ED, Arisan S, Atis G, Palavan-Unsal N, Ergenekon E. Serum adipocytokine levels in prostate cancer patients. Urol Int 
2009;82:203-8.

97. Goktas S, Yilmaz MI, Caglar K, Sonmez A, Kilic S, et al. Prostate cancer and adiponectin. Urology 2005;65:1168-72.

98. Baillargeon J, Platz EA, Rose DP, Pollock BH, Ankerst DP, et al. Obesity, adipokines, and prostate cancer in a prospective population-based study. Cancer Epidemiol Biomarkers Prev 2006;15:1331-5.

99. Kerenidi T, Lada M, Tsaroucha A, Georgoulias P, Mystridou P, et al. Clinical significance of serum adipokines levels in lung cancer. Med Oncol 2013;30:507.

100. Karapanagiotou EM, Tsochatzis EA, Dilana KD, Tourkantonis I, Gratsias I, et al. The significance of leptin, adiponectin, and resistin serum levels in non-small cell lung cancer (NSCLC). Lung Cancer 2008;61:391-7.

101. Petridou ET, Sergentanis TN, Antonopoulos CN, Dessypris N, Matsoukis IL, et al. Insulin resistance: an independent risk factor for lung cancer? Metabolism 2011;60:1100-6.

102. Iwabu M, Yamauchi T, Okada-Iwabu M, Sato K, Nakagawa T, et al. Adiponectin and AdipoR1 regulate PGC-1 $\alpha$ and mitochondria by Ca2+ and AMPK/SIRT1. Nature 2010;464:1313-9.

103. Yamauchi T, Kamon J, Minokoshi Y, Ito Y, Waki H, et al. Adiponectin stimulates glucose utilization and fatty-acid oxidation by activating AMP-activated protein kinase. Nat Med 2002;8:1288-95.

104. Li W, Saud SM, Young MR, Chen G, Hua B. Targeting AMPK for cancer prevention and treatment. Oncotarget 2015;6:7365-78.

105. Engelman JA, Chen L, Tan X, Crosby K, Guimaraes AR, et al. Effective use of PI3K and MEK inhibitors to treat mutant Kras G12D and PIK3CA H1047R murine lung cancers. Nat Med 2008;14:1351-6.

106. Majumder PK, Febbo PG, Bikoff R, Berger R, Xue Q, et al. mTOR inhibition reverses Akt-dependent prostate intraepithelial neoplasia through regulation of apoptotic and HIF-1-dependent pathways. Nat Med 2004;10:594-601.

107. Paquette M, El-Houjeiri L, Pause A. mTOR Pathways in Cancer and Autophagy. Cancers (Basel) 2018;10:18.

108. Meisse D, Van de Casteele M, Beauloye C, Hainault I, Kefas BA, et al. Sustained activation of AMP-activated protein kinase induces c-Jun N-terminal kinase activation and apoptosis in liver cells. FEBS Lett 2002;526:38-42.

109. Kuhajda FP. AMP-activated protein kinase and human cancer: cancer metabolism revisited. Int J Obes 2008;32:S36-41.

110. Yano S, Tokumitsu H, Soderling TR. Calcium promotes cell survival through CaM-K kinase activation of the protein-kinase-B pathway. Nature 1998;396:584-7.

111. Habeeb BS, Kitayama J, Nagawa H. Adiponectin supports cell survival in glucose deprivation through enhancement of autophagic response in colorectal cancer cells. Cancer Sci 2011;102:999-1006.

112. Lam JB, Chow KH, Xu A, Lam KS, Liu J, et al. Adiponectin haploinsufficiency promotes mammary tumor development in MMTV-PyVT mice by modulation of phosphatase and tensin homolog activities. PLoS One 2009;4:e4968.

113. Karim R, Tse G, Putti T, Scolyer R, Lee S. The significance of the Wnt pathway in the pathology of human cancers. Pathology 2004;36:120-8.

114. Yu H, Pardoll D, Jove R. STATs in cancer inflammation and immunity: a leading role for STAT3. Nat Rev Cancer 2009;9:798-809.

115. Miyazaki T, Bub JD, Uzuki M, Iwamoto Y. Adiponectin activates c-Jun NH2-terminal kinase and inhibits signal transducer and activator of transcription 3. Biochem Biophys Res Commun 2005;333:79-87.

116. Saxena NK, Fu PP, Nagalingam A, Wang J, Handy J, et al. Adiponectin modulates C-jun N-terminal kinase and mammalian target of rapamycin and inhibits hepatocellular carcinoma. Gastroenterology 2010;139:1762-73, 1773.e1-5.

117. Tan PH, Tyrrell HEJ, Gao L, Xu D, Quan J, et al. Adiponectin receptor signaling on dendritic cells blunts antitumor immunity. Cancer Res 2014;74:5711-22.

118. Chen MJ, Yeh YT, Lee KT, Tsai CJ, Lee HH, et al. The promoting effect of adiponectin in hepatocellular carcinoma. J Surg Oncol 2012;106:181-7.

119. Chung SJ, Nagaraju GP, Nagalingam A, Muniraj N, Kuppusamy P, et al. ADIPOQ/adiponectin induces cytotoxic autophagy in breast cancer cells through STK11/LKB1-mediated activation of the AMPK-ULK1 axis. Autophagy 2017;13:1386-403.

120. Guo W, Wang Y, Wang Z, Wang YP, Zheng H. Inhibiting autophagy increases epirubicin's cytotoxicity in breast cancer cells. Cancer Sci 2016;107:1610-21.

121. Xia JY, Holland WL, Kusminski CM, Sun K, Sharma AX, et al. Targeted induction of ceramide degradation leads to improved systemic metabolism and reduced hepatic steatosis. Cell Metab 2015;22:266-78.

122. Aerts JM, Ottenhoff R, Powlson AS, Grefhorst A, Eijk M van, et al. Pharmacological inhibition of glucosylceramide synthase enhances insulin sensitivity. Diabetes 2007;56:1341-9.

123. Holland WL, Miller RA, Wang ZV, Sun K, Barth BM, et al. Receptor-mediated activation of ceramidase activity initiates the pleiotropic actions of adiponectin. Nat Med 2011;17:55-63.

124. Obata Y, Kita S, Koyama Y, Fukuda S, Takeda H, et al. Adiponectin/T-cadherin system enhances exosome biogenesis and decreases cellular ceramides by exosomal release. JCI Insight 2018;3:99680.

125. Andreeva AV, Kutuzov MA. Cadherin 13 in cancer. Genes Chromosomes Cancer 2010;49:775-90.

126. Lengyel E, Makowski L, DiGiovanni J, Kolonin MG. Cancer as a matter of fat: the crosstalk between adipose tissue and tumors. Trends Cancer 2018;4:374-84.

127. Wolf AM, Wolf D, Rumpold H, Enrich B, Tilg H. Adiponectin induces the anti-inflammatory cytokines IL-10 and IL-1RA in human leukocytes. Biochem Biophys Res Commun 2004;323:630-5.

128. Qi GM, Jia LX, Li YL, Li HH, Du J. Adiponectin suppresses angiotensin II-induced inflammation and cardiac fibrosis through activation of macrophage autophagy. Endocrinology 2014;155:2254-65.

129. Park P, Huang H, McMullen MR, Bryan K, Nagy LE. Activation of cyclic-AMP response element binding protein contributes to adiponectin-stimulated interleukin-10 expression in raw 264.7 macrophages. J Leukoc Biol 2008;83:1258-66.

130. Mandal P, Pratt BT, Barnes M, McMullen MR, Nagy LE. Molecular mechanism for adiponectin-dependent M2 macrophage polarization: link between the metabolic and innate immune activity of full-length adiponectin. J Biol Chem 2011;286:13460-9.

131. Wulster-Radcliffe MC, Ajuwon KM, Wang J, Christian JA, Spurlock ME. Adiponectin differentially regulates cytokines in porcine 
macrophages. Biochem Biophys Res Commun 2004;316:924-9.

132. Kyriazi E, Tsiotra PC, Boutati E, Ikonomidis I, Fountoulaki K, et al. Effects of adiponectin in TNF-alpha, IL-6, and IL-10 cytokine production from coronary artery disease macrophages. Horm Metab Res 2011;43:537-44.

133. Park PH, McMullen MR, Huang H, Thakur V, Nagy LE. Short-term treatment of RAW264.7 macrophages with adiponectin increases tumor necrosis factor-alpha (TNF-alpha) expression via ERK1/2 activation and Egr-1 expression: role of TNF-alpha in adiponectin-stimulated interleukin-10 production. J Biol Chem 2007;282:21695-703.

134. Luo N, Wang X, Chung BH, Lee MH, Klein RL, et al. Effects of macrophage-specific adiponectin expression on lipid metabolism in vivo. Am J Physiol Endocrinol Metab 2011;301:E180-6.

135. Kumada M, Kihara S, Ouchi N, Kobayashi H, Okamoto Y, et al. Adiponectin specifically increased tissue inhibitor of metalloproteinase-1 through interleukin-10 expression in human macrophages. Circulation 2004;109:2046-9.

136. Kollias A, Tsiotra PC, Ikonomidis I, Maratou E, Mitrou P, et al. Adiponectin levels and expression of adiponectin receptors in isolated monocytes from overweight patients with coronary artery disease. Cardiovasc Diabetol 2011;10:14.

137. Kamio N, Akifusa S, Yamaguchi N, Nonaka K, Yamashita Y. Anti-inflammatory activity of a globular adiponectin function on RAW 264 cells stimulated by lipopolysaccharide from Aggregatibacter actinomycetemcomitans. FEMS Immunol Med Microbiol 2009;56:241-7.

138. Huang H, Park PH, McMullen MR, Nagy LE. Mechanisms for the anti-inflammatory effects of adiponectin in macrophages. J Gastroenterol Hepatol 2008;23:S50-3.

139. Yamauchi T, Kamon J, Waki H, Imai Y, Shimozawa N, et al. Globular adiponectin protected ob/ob mice from diabetes and ApoE-deficient mice from atherosclerosis. J Biol Chem 2003;278:2461-8.

140. Zhang C, Liao Y, Li Q, Chen M, Zhao Q, et al. Recombinant adiponectin ameliorates liver ischemia reperfusion injury via activating the AMPK/eNOS pathway. PLoS One 2013;8:e66382.

141. Okamoto Y, Folco EJ, Minami M, Wara AK, Feinberg MW, et al. Adiponectin inhibits the production of CXC receptor 3 chemokine ligands in macrophages and reduces T-lymphocyte recruitment in atherogenesis. Circ Res 2008;102:218-25.

142. Summer R, Little FF, Ouchi N, Takemura Y, Aprahamian T, et al. Alveolar macrophage activation and an emphysema-like phenotype in adiponectin-deficient mice. Am J Physiol Lung Cell Mol Physiol 2008;294:L1035-42.

143. Okamoto Y, Ishii S, Croce K, Katsumata H, Fukushima M, et al. Adiponectin inhibits macrophage tissue factor, a key trigger of thrombosis in disrupted atherosclerotic plaques. Atherosclerosis 2013;226:373-7.

144. Yokota T, Oritani K, Takahashi I, Ishikawa J, Matsuyama A, et al. Adiponectin, a new member of the family of soluble defense collagens, negatively regulates the growth of myelomonocytic progenitors and the functions of macrophages. Blood 2000;96:1723-32.

145. Tan PH, Tyrrell HE, Gao L, Xu D, Quan J, et al. Adiponectin receptor signaling on dendritic cells blunts anti-tumor immunity. Cancer Res 2014;74:5711-22.

146. Tsang JY, Li D, Ho D, Peng J, Xu A, et al. Novel immunomodulatory effects of adiponectin on dendritic cell functions. Int Immunopharmacol 2011;11:604-9.

147. Wang Y, Wang X, Lau WB, Yuan Y, Booth D, et al. Adiponectin inhibits tumor necrosis factor-alpha-induced vascular inflammatory response via caveolin-mediated ceramidase recruitment and activation. Circ Res 2014;114:792-805.

148. van Meurs M, Castro P, Shapiro NI, Lu S, Yano M, et al. Adiponectin diminishes organ-specific microvascular endothelial cell activation associated with sepsis. Shock 2012;37:392-8.

149. Okamoto Y, Christen T, Shimizu K, Asano K, Kihara S, et al. Adiponectin inhibits allograft rejection in murine cardiac transplantation. Transplantation 2009;88:879-83.

150. Zhi Z, Pengfei Z, Xiaoyi T, Genshan M. Adiponectin ameliorates angiotensin II-induced vascular endothelial damage. Cell Stress Chaperones 2014;19:705-13

151. Yu F, Chen R, Takahashi T, Sumino H, Morimoto S, et al. Candesartan improves myocardial damage in obese mice with viral myocarditis and induces cardiac adiponectin. Int J Cardiol 2008;129:414-21.

152. Konter JM, Parker JL, Baez E, Li SZ, Ranscht B, et al. Adiponectin attenuates lipopolysaccharide-induced acute lung injury through suppression of endothelial cell activation. J Immunol 2012;188:854-63.

153. Kobashi C, Urakaze M, Kishida M, Kibayashi E, Kobayashi H, et al. Adiponectin inhibits endothelial synthesis of interleukin-8. Circ Res 2005;97:1245-52.

154. Shibata R, Skurk C, Ouchi N, Galasso G, Kondo K, et al. Adiponectin promotes endothelial progenitor cell number and function. FEBS Lett 2008;582:1607-12.

155. Kim KY, Kim JK, Han SH, Lim JS, Kim KI, et al. Adiponectin is a negative regulator of NK cell cytotoxicity. J Immunol 2006; 176:5958-64.

156. Wilk S, Scheibenbogen C, Bauer S, Jenke A, Rother M, et al. Adiponectin is a negative regulator of antigen-activated T cells. Eur J Immunol 2011:41:2323-32.

157. Yokota T, Meka CS, Kouro T, Medina KL, Igarashi H, et al. Adiponectin, a fat cell product, influences the earliest lymphocyte precursors in bone marrow cultures by activation of the cyclooxygenase-prostaglandin pathway in stromal cells. J Immunol 2003;171:5091-9.

158. Awazawa M, Ueki K, Inabe K, Yamauchi T, Kubota N, et al. Adiponectin enhances insulin sensitivity by increasing hepatic IRS-2 expression via a macrophage-derived IL-6-dependent pathway. Cell Metab 2011;13:401-12.

159. Jung MY, Kim HS, Hong HJ, Youn BS, Kim TS. Adiponectin induces dendritic cell activation via PLCgamma/JNK/NF-kappaB pathways, leading to Th1 and Th17 polarization. J Immunol 2012;188:2592-601.

160. Cheng X, Folco EJ, Shimizu K, Libby P. Adiponectin induces Pro-inflammatory programs in human macrophages and CD4 + T cells. J Biol Chem 2012;287:36896-904.

161. Wanninger J, Neumeier M, Weigert J, Bauer S, Weiss TS, et al. Adiponectin-stimulated CXCL8 release in primary human hepatocytes is regulated by ERK1/ERK2, p38 MAPK, NF-kappaB, and STAT3 signaling pathways. Am J Physiol Gastrointest Liver Physiol 2009;297:G611-8. 
162. Tang CH, Chiu YC, Tan TW, Yang RS, Fu WM. Adiponectin enhances IL-6 production in human synovial fibroblast via an AdipoR1 receptor, AMPK, p38, and NF-kappa B pathway. J Immunol 2007;179:5483-92.

163. Fan D, Li L, Wang C, Cui XB, Zhou Y, et al. Adiponectin induces interleukin-6 production and its underlying mechanism in adult rat cardiac fibroblasts. J Cell Physiol 2011;226:1793-802.

164. Couper KN, Blount DG, Riley EM. IL-10: the master regulator of immunity to infection. J Immunol 2008;180:5771-7.

165. Melillo JA, Song L, Bhagat G, Blazquez AB, Plumlee CR, et al. Dendritic Cell (DC)-Specific Targeting Reveals Stat3 as a Negative Regulator of DC Function. J Immunol 2010;184:2638-45.

166. Williams L, Bradley L, Smith A, Foxwell B. Signal transducer and activator of transcription 3 is the dominant mediator of the antiinflammatory effects of IL-10 in human macrophages. J Immunol 2004;172:567-76.

167. El Kasmi KC, Smith AM, Williams L, Neale G, Panopoulos AD, et al. Cutting edge: A transcriptional repressor and corepressor induced by the STAT3-regulated anti-inflammatory signaling pathway. J Immunol 2007;179:7215-9.

168. Folco EJ, Rocha VZ, López-Ilasaca M, Libby P. Adiponectin inhibits Pro-inflammatory signaling in human macrophages independent of interleukin-10. J Biol Chem 2009;284:25569-75.

169. Ohashi K, Parker JL, Ouchi N, Higuchi A, Vita JA, et al. Adiponectin promotes macrophage polarization toward an anti-inflammatory phenotype. J Biol Chem 2010;285:6153-60.

170. Ouchi N, Kobayashi H, Kihara S, Kumada M, Sato K, et al. Adiponectin stimulates angiogenesis by promoting cross-talk between AMPactivated protein kinase and Akt signaling in endothelial cells. J Biol Chem 2004;279:1304-9.

171. Ohashi K, Kihara S, Ouchi N, Kumada M, Fujita K, et al. Adiponectin replenishment ameliorates obesity-related hypertension. Hypertension 2006; 47:1108-16.

172. Shibata R, Ouchi N, Ito M, Kihara S, Shiojima I, et al. Adiponectin-mediated modulation of hypertrophic signals in the heart. Nat Med 2004; $10: 1384-9$.

173. Denzel MS, Scimia MC, Zumstein PM, Walsh K, Ruiz-Lozano P, et al. T-cadherin is critical for adiponectin-mediated cardioprotection in mice. J Clin Invest 2010;120:4342-52.

174. Ohashi K, Ouchi N, Sato K, Higuchi A, Ishikawa TO, et al. Adiponectin promotes revascularization of ischemic muscle through a cyclooxygenase 2-dependent mechanism. Mol Cell Biol 2009;29:3487-99.

175. Masaie H, Oritani K, Yokota T, Takahashi I, Shirogane T, et al. Adiponectin binds to chemokines via the globular head and modulates interactions between chemokines and heparan sulfates. Exp Hematol 2007;35:947-56.

176. Gosset P, Charbonnier AS, Delerive P, Fontaine J, Staels B, et al. Peroxisome proliferator-activated receptor gamma activators affect the maturation of human monocyte-derived dendritic cells. Eur J Immunol 2001;31:2857-65.

177. Li Y, Chu N, Rostami A, Zahng GX. Dendritic cells transduced with SOCS-3 exhibit a tolerogenic/DC2 phenotype that directs type 2 Th cell differentiation in vitro and in vivo. J Immunol 2006;177:16779-88.

178. Robbins PD, Morelli AE. Regulation of immune responses by extracellular vesicles. Nat Rev Immunol 2014;14:195-208.

179. Lai RC, Arslan F, Lee MM, Sze NS, Choo A, et al. Exosome secreted by MSC reduces myocardial ischemia/reperfusion injury. Stem Cell Res 2010;4:214-22.

180. Hui X, Gu P, Zhang J, Nie T, Pan Y, et al. Adiponectin enhances cold-induced browning of subcutaneous adipose tissue via promoting M2 macrophage proliferation. Cell Metab 2015;22:279-90.

181. Kyriazi E, Tsiotra PC, Boutati E, Ikonomidis I, Fountoulaki K, et al. Effects of Adiponectin in TNF- $\alpha$, IL-6, and IL-10 cytokine production from coronary artery disease macrophages. Horm Metab Res 2011;43:537-44.

182. Mandal P, Pratt BT, Barnes M, McMullen MR, Nagy LE. Molecular mechanism for adiponectin-dependent M2 macrophage polarization. J Biol Chem 2011;286:13460-9.

183. Gove ME, Pini M, Fayad R, Cabay RJ, Fantuzzi G. Adiponectin deficiency modulates adhesion molecules expression and cytokine production but does not affect disease severity in the transfer model of colitis. Cytokine 2009;47:119-25.

184. Komura N, Maeda N, Mori T, Kihara S, Nakatsuji H, et al. Adiponectin protein exists in aortic endothelial cells. PLoS One 2013;8:e71271.

185. Park P, McMullen MR, Huang H, Thakur V, Nagy LE. Short-term treatment of RAW264.7 macrophages with adiponectin increases tumor necrosis factor- $\alpha$ (TNF- $\alpha$ ) expression via ERK1/2 activation and Egr-1 expression: role of TNF-alpha in adiponectin-stimulated interleukin-10 production. J Biol Chem 2007;282:21695-703.

186. Jung MY, Kim HS, Hong HJ, Youn BS, Kim TS. Adiponectin induces dendritic cell activation via PLC $\gamma / \mathrm{JNK} / \mathrm{NF}-\kappa \mathrm{B}$ pathways, leading to Th1 and Th17 polarization. J Immunol 2012;188:2592-601.

187. Katsuki A, Sumida Y, Urakawa H, Gabazza EC, Murashima S, et al. Plasma levels of adiponectin are associated with insulin resistance and serum levels of triglyceride in Japanese metabolically obese, normal-weight men with normal glucose tolerance. Diabetes Care 2003;26:2964-5.

188. Tan PH, Sagoo P, Chan C, Yates JB, Campbell J, et al. Inhibition of NF-kappa B and oxidative pathways in human dendritic cells by antioxidative vitamins generates regulatory T cells. J Immunol 2005;174:7633-44.

189. Kriketos AD, Gan SK, Poynten AM, Furler SM, Chisholm DJ, et al. Exercise increases adiponectin levels and insulin sensitivity in humans. Diabetes Care 2004;27:629-30.

190. Chinetti G, Zawadski C, Fruchart JC, Staels B. Expression of adiponectin receptors in human macrophages and regulation by agonists of the nuclear receptors PPARalpha, PPARgamma, and LXR. Biochem Biophys Res Commun 2004;314:151-8.

191. Tomizawa A, Hattori Y, Kasai K, Nakano Y. Adiponectin induces NF-kB activation that leads to suppression of cytokine-induced NF- $\mathrm{kB}$ activation in vascular endothelial cells: globular adiponectin vs. high molecular weight adiponectin. Diab Vasc Dis Res 2008;5:123-7.

192. Otvos Jr L, Haspinger E, La Russa F, Maspero F, Graziano P, et al. Design and development of a peptide-based adiponectin receptor agonist for cancer treatment. BMC Biotechnol 2011;11:90.

193. Otvos L Jr, Kovalszky I, Olah J, Coroniti R, Knappe D, et al. Optimization of adiponectin-derived peptides for inhibition of cancer cell growth and signaling. Biopolymers 2015;104:156-66. 
194. Sun Y, Zang Z, Zhong L, Wu M, Su Q, et al. Identification of adiponectin receptor agonist utilizing a fluorescence polarization based high throughput assay. PLoS One 2013;8:e63354.

195. Okada-Iwabu M, Yamauchi T, Iwabu M, Honma T, Hamagami K, et al. A small-molecule AdipoR agonist for type 2 diabetes and short life in obesity. Nature 2013;503:493-9.

196. Yousefnia S, Momenzadeh S, Seyed Forootan F, Ghaedi K, Nasr Esfahani MH. The influence of peroxisome proliferator-activated receptor $\gamma(\operatorname{PPAR} \gamma)$ ligands on cancer cell tumorigenicity. Gene 2018;649:14-22.

197. Maeda N, Takahashi M, Funahashi T, Kihara S, Nishizawa H, et al. PPARgamma ligands increase expression and plasma concentrations of adiponectin, an adipose-derived protein. Diabetes 2001;50:2094-9.

198. Murakami H, Ono A, Takahashi T, Onozawa Y, Tsushima T, et al. Phase I study of Efatutazone, an oral PPAR $\gamma$ agonist, in patients with metastatic solid tumors. Anticancer Res 2014;34:5133-41.

199. Komatsu Y, Yoshino T, Yamazaki K, Yuki S, Machida N, et al. Phase 1 study of efatutazone, a novel oral peroxisome proliferator-activated receptor gamma agonist, in combination with FOLFIRI as second-line therapy in patients with metastatic colorectal cancer. Invest New Drugs 2014;32:473-80.

200. Smallridge RC, Copland JA, Brose MS, Wadsworth JT, Houvras Y, et al. Efatutazone, an oral PPAR- $\gamma$ agonist, in combination with paclitaxel in anaplastic thyroid cancer: results of a multicenter phase 1 trial. J Clin Endocrinol Metab 2013;98:2392-400.

201. Boucher E, Davidenko I, Hadler D, Roemeling R von, Aprile G. PD-0008 * a randomized, placebo-controlled, phase 2 study of efatutazone maintenance therapy in patients with advanced colorectal cancer who have achieved disease control following first-line chemotherapy. Ann Oncol 2014;25:ii8.

202. Williams R. Discontinued in 2013: oncology drugs. Expert Opin Investig Drugs 2015;24:95-110.

203. Chang S, Lee J, Oh H, Kim U, Ryu B, et al. Troglitazone inhibits the migration and invasion of PC-3 human prostate cancer cells by upregulating E-cadherin and glutathione peroxidase 3. Oncol Lett 2018;16:5482-8.

204. Hong OY, Youn HJ, Jang HY, Jung SH, Noh EM, et al. Troglitazone inhibits matrix metalloproteinase-9 expression and invasion of breast cancer cell through a peroxisome proliferator-activated receptor $\gamma$-dependent mechanism. J Breast Cancer 2018;21:28.

205. Fujita M, Hasegawa A, Yamamori M, Okamura N. In vitro and in vivo cytotoxicity of troglitazone in pancreatic cancer. J Exp Clin Cancer Res 2017;36:91

206. Nazim U, Moon JH, Lee YJ, Seol JW, Park SY. PPAR $\gamma$ activation by troglitazone enhances human lung cancer cells to TRAIL-induced apoptosis via autophagy flux. Oncotarget 2017;8:26819-31.

207. Burstein HJ, Demetri GD, Mueller E, Sarraf P, Spiegelman BM, et al. Use of the peroxisome proliferator-activated receptor (PPAR) gamma ligand troglitazone as treatment for refractory breast cancer: a phase II study. Breast Cancer Res Treat 2003;79:391-7.

208. Kulke MH, Demetri GD, Sharpless NE, Ryan DP, Shivdasani R, et al. A phase II study of troglitazone, an activator of the PPARgamma receptor, in patients with chemotherapy-resistant metastatic colorectal cancer. Cancer J 2002;8:395-9.

209. Wei S, Yang J, Lee SL, Kulp SK, Chen CS. PPAR $\gamma$-independent antitumor effects of thiazolidinediones. Cancer Lett 2009;276:119-24

210. Kanda S, Nakashima R, Takahashi K, Tanaka J, Ogawa J, et al. Potent antidiabetic effects of rivoglitazone, a novel peroxisome proliferatoractivated receptor-gamma agonist, in obese diabetic rodent models. J Pharmacol Sci 2009;111:155-66.

211. Hiuge-Shimizu A, Maeda N, Hirata A, Nakatsuji H, Nakamura K, et al. Dynamic changes of adiponectin and S100A8 levels by the selective peroxisome proliferator-activated receptor- $\gamma$ agonist rivoglitazone. Arterioscler Thromb Vasc Biol 2011;31:792-9.

212. Debrock G, Vanhentenrijk V, Sciot R, Debiec-Rychter M, Oyen R, et al. A phase II trial with rosiglitazone in liposarcoma patients. Br J Cancer 2003;89:1409-12.

213. Lu CJ, Sun Y, Muo CH, Chen RC, Chen PC, et al. Risk of stroke with thiazolidinediones: a ten-year nationwide population-based cohort study. Cerebrovasc Dis 2013;36:145-51.

214. Holland WL, Scherer PE. Cell Biology. Ronning after the adiponectin receptors. Science 2013;342:1460-1.

215. Muppala S, Konduru SKP, Merchant N, Ramsoondar J, Rampersad CK, et al. Adiponectin: its role in obesity-associated colon and prostate cancers. Crit Rev Oncol Hematol 2017;116:125-33.

216. Ziemke F, Mantzoros CS. Adiponectin in insulin resistance: lessons from translational research. Am J Clin Nutr 2010;91:258S-261S

217. Lee SH, Hong HR, Han TK, Kang HS. Aerobic training increases the expression of adiponectin receptor genes in the peripheral blood mononuclear cells of young men. Biol Sport 2015;32:181-6.

218. Coussens LM, Werb Z. Inflammation and cancer. Nature 2002;420:860-7.

219. Cnop M, Havel PJ, Utzschneider KM, Carr DB, Sinha MK, et al. Relationship of adiponectin to body fat distribution, insulin sensitivity and plasma lipoproteins: evidence for independent roles of age and sex. Diabetologia 2003;46:459-69. 